NBER WORKING PAPER SERIES

\title{
HOW LAW AND INSTITUTIONS SHAPE FINANCIAL CONTRACTS: THE CASE OF BANK LOANS
}

\author{
Jun Qian \\ Philip E. Strahan \\ Working Paper 11052 \\ http://www.nber.org/papers/w11052 \\ NATIONAL BUREAU OF ECONOMIC RESEARCH \\ 1050 Massachusetts Avenue \\ Cambridge, MA 02138 \\ January 2005
}

We appreciate helpful comments from Franklin Allen, Thorsten Beck, Ross Levine, Andrei Shleifer, Amir Sufi, and seminar/session participants at Bank of England, Boston College, Federal Deposit Insurance Corporation, Federal Reserve Banks of New York and Philadelphia, Harvard, INSEAD, London Business School, and the Financial Intermediation Research Society meetings in Capri, Italy. Geraldine Hough, JeanMarc Donics, Daniel Yang, and Zhe Xu provided excellent research assistance. Financial support from Boston College is gratefully acknowledged. The authors are responsible for all remaining errors. The views expressed herein are those of the author(s) and do not necessarily reflect the views of the National Bureau of Economic Research.

(c) 2005 by Jun Qian and Philip E. Strahan. All rights reserved. Short sections of text, not to exceed two paragraphs, may be quoted without explicit permission provided that full credit, including $\odot$ notice, is given to the source. 
How Law and Institutions Shape Financial Contracts: The Case of Bank Loans

Jun Qian and Jun Qian

NBER Working Paper No. 11052

January 2005

JEL No. K0, G2, O5

\title{
ABSTRACT
}

We examine empirically how legal origin, creditor rights, property rights, legal formalism, and financial development affect the design of price and non-price terms of bank loans in almost 60 countries. Our results support the law and finance view that private contracts reflect differences in legal protection of creditors and the enforcement of contracts. Loans made to borrowers in countries where creditors can seize collateral in case of default are more likely to be secured, have longer maturity, and have lower interest rates. We also find evidence, however, that ?Coasian? bargaining can partially offset weak legal or institutional arrangements. For example, lenders mitigate risks associated with weak property rights and government corruption by securing loans with collateral and shortening maturity. Our results also suggest that the choice of loan ownership structure affects loan contract terms.

\author{
Jun Qian \\ Boston College \\ Chestnut Hill, MA \\ qianju@bc.edu \\ Philip E. Strahan \\ Carroll School of Management \\ 324B Fulton Hall \\ Boston College \\ Chestnut Hill, MA 02467 \\ and NBER \\ philip.strahan@bc.edu
}




\section{Introduction}

In recent years, a substantial body of empirical evidence has linked laws and institutions to the development of financial and economic systems. Pioneered and developed by La Porta, Lopez-de-Silanes, Shleifer, and Vishny (LLSV hereafter), among other authors, this literature documents that the historical origin of a country's legal system, in particular, countries with English common-law origin vs. French civil-law origin, is strongly correlated with financial and economic "outcomes". For example, countries with English origin (French origin) provide the strongest (weakest) legal protections to both shareholders and creditors (LLSV, 1998, 2000a). Countries with English origin also seem to have better institutions, including less corrupt governments (LLSV, 1999), more efficient courts and bankruptcy procedures (Djankov, La Porta, Lopez-de-Silanes, and Shleifer, DLLS hereafter, 2003), and more informative accounting standards. These better institutions, in turn, seem to lead to better outcomes for the financial system. Relative to firms in French-origin countries, firms in English-origin countries have more dispersed shareholder ownership (La Porta, Lopez-de-Silanes, and Shleifer, LLS hereafter, 1999), rely more on external capital markets to raise funds (LLSV, 1997), have higher values (LLSV, 2002), and can enter a new market or industry more easily (DLLS, 2002).

Despite these connections from legal origin to institutions to financial/economic outcomes, less is known about how these three links connect and relate to each other. In particular, does legal origin, through its shaping of a country's laws and institutions, cause observed differences in outcomes? If so, through what channels? Related to the LLSV results, there is evidence that legal origin does play an important role in explaining differences in financial systems and in economic growth. ${ }^{1}$ For example, the English common law system is superior to the French civil law system

\footnotetext{
${ }^{1}$ First, there is the finance and growth literature supporting the view that developing financial system stimulates economic growth (e.g., McKinnon, 1973; King and Levine, 1993; Levine and Zervos, 1998). The second strand of literature attempts to establish the link and causality of law, finance, and growth: for example, Levine (1999) provides
} 
in its ability to adapt to evolving economic conditions (e.g., Hayek, 1960; Posner, 1973; Beck, Demirgüç-Kunt, and Levine, 2003b). As a result, firms in French civil law countries face higher obstacles in accessing external finance than those in English common law countries (e.g., Beck et al., 2003c). ${ }^{2}$

There are factors, however, that can alter the financial and economic outcomes as predicted by LLSV papers. Perhaps the most important of these factors flows from the Coasian view that, with low transactions costs, individuals can privately contract and protect each other's rights and interests irrespective of the law. According to this logic, "Coasian bargaining" allows agents to undo the detrimental effects of a weak legal system. If some private contract terms substitute for legal protections, for example, then links between legal institutions and outcomes ought to be partially - or even fully - offset. It is reasonable to believe that an important aspect of the transaction costs in Coasian bargaining is the efficiency of a country's institutions. ${ }^{3}$

This paper studies how laws and institutions in different countries shape the ownership of bank loans as well as the price and non-price terms of these contracts. We employ a data set of loans originated between 1994 to 2003 in about 60 countries, and test how loan terms vary across countries in a reduced form setting. We argue that bank loan contracts depend on country-level variables incorporating legal and institutional factors, and on loan-level variables incorporating borrower and loan characteristics. Our main focus is on the effects of country-level factors.

evidence at country level, Rajan and Zingales (1998) at the industry level, and Demirgüç-Kunt and Maksimovic (1998) find firm-level evidence. Jayaratne and Strahan (1996) show that financial deregulation in U.S. banking was followed by accelerated growth.

${ }^{2}$ Other endeavors on understanding institutions include examining the endowment of geography and disease environment in former colonial countries (e.g., Acemoglu, Johnson, and Robinson, 2001, 2002; Beck, DemirgüçKunt, and Levine, 2003a), property rights (e.g., Johnson, McMillan, and Woodruff, 2002), and religion and cultural beliefs (e.g., Greif, 1994; Stulz and Williamson, 2003).

${ }^{3}$ In this regard, Acemoglu and Johnson (2003) differentiate laws and institutions governing transactions between the government/elites and ordinary citizens (property rights institutions) from those governing the transactions among ordinary citizens (contracting institutions). 
Specifically, we examine the basic pricing term (the interest rate), two non-price terms (loan maturity and the secured status of the loan), along with three ownership variables (the number of lenders, the share of each loan held by banks located in the same country as the borrower, and the share of each loan held by government-owned banks). We test how these loan attributes vary with differences in creditor rights, property rights, government corruption, the functioning of the courts, and financial and economic development. While other studies have tested how a single dimension of the loan contract responds to country-level variables, ours is the first to explore in a multivariate setting how ownership and contracts are determined. This multi-dimensional approach allows us to provide a more complete characterization of how the overall availability of credit may respond to the contracting environment. ${ }^{4}$

We draw three broad conclusions from our findings. First, consistent with the law and finance view, a country's laws and institutions are important in shaping private contracts. We find that protection of creditors' rights in the law is perhaps the most important of these factors. Unlike most existing research, we differentiate creditor rights along two different dimensions: Creditors' ability to seize collateral in the case of default versus their ability to oust incumbent management during reorganization. We find that creditors' ability to take collateral is crucial in shaping terms of the loan contracts, while their ability to oust management is not. For example, as creditor's ability to take collateral increases, bank loans are more likely to be secured by collateral, and tend to have longer maturity and lower interest rates. Our results suggest that a contract term that potentially reduces lender risk - collateral - is seen most commonly where it is most easily

\footnotetext{
${ }^{4}$ Giannetti (2003) links private firms' financing decisions including loans to cross-country institutional variables, whereas Esty and Megginson (2003) consider only loan ownership and Esty (2004) considers foreign (loan) ownership. Outside of lending, Jappelli et al. (2002) look at mortgage markets and judicial efficiencies; Bergman and Nicolaeivsky (2003) look at corporate charters before and after IPO in Mexico; Kaplan, Martel, and Stromberg (2003) and Lerner and Schoar (2004) examine private equity contracts in developed and developing countries; Aggarwal, Klapper, and Wysocki (2003) examine the investment allocation choices of actively-managed US mutual funds in emerging economies; and Rossi and Volpin (2004) examine cross-country determinants of mergers and acquisitions. Finally, Sufi (2004) examines loan ownership in the U.S.
} 
enforceable in the law. Consistent with this interpretation, once banks secure the loan with collateral, firms can borrow at a lower cost, as loan interest rates decline when creditor rights strengthen. How do lenders insure repayment where creditor rights are weak? First, in addition to imposing higher interest rates, lenders 'put the borrower on a short leash' by reducing maturity. Second, loan ownership is more diffuse in countries with weak creditor rights protection. Diffusion of ownership reduces the risk to lenders directly via diversification, but it also may preclude borrowers from engaging in strategic default by increasing the ex-post cost of restructuring bad loans (e.g., Bolton and Scharfstein, 1996; Esty and Megginson, 2003; Diamond, 2004). Thus, loan ownership may act as yet another tool for lenders operating in countries where their bargaining power is otherwise relatively weak (due to the legal arrangement).

We also find that greater legal formalism in a borrower's country, previously shown in DLLS (2003) to lead to slower and less efficient courts, significantly alters the terms of loan contracts. First, loans made in countries with greater formalism are more likely to be secured and tend to have longer maturity. Second, legal formalism seems to affect the terms of the contracts differently for rated vs. unrated firms. With greater formalism, a larger fraction of unrated loans are owned by domestic banks (banks located in the same country as the borrower), while the opposite is true for rated loans. Moreover, interest rates on loans to rated borrowers rise with more formalism, whereas rates are unrelated to formalism for loans to unrated borrowers. We argue that interest rates on loans to unrated borrowers, where local lenders are dominant, do not reflect the costs of using the courts (legal formalism) because local lenders usually re-contract or workout loans privately. In contrast, interest rates to rated borrowers increase with the costs of using courts because foreign lenders expect to use courts for defaulted loans. This interpretation is consistent with Mian (2004), who finds that foreign lenders in Pakistan are more likely to use courts to restructure defaulted loans, compared to domestic banks. Overall our results are 
consistent with the implications from DLLS (2003), who find that more legal formalism raises contracting costs.

Second, our results document the potential importance of 'Coasian bargaining' in offsetting the costs of a weak institutional or legal framework. For example, government corruption and property rights, while very significant in explaining collateral and maturity, are not significantly related to loan interest rates. ${ }^{5}$ This suggests that much of the risks associated with lending in countries where legal protections are weak and government expropriation risk is high may be substantially mitigated through private contracting. For example, the use of collateral decreases as property rights protection improves, whereas loan maturity increases significantly when government corruption improves. Thus, where the risk of government expropriation is high, banks seem able to protect themselves with collateral and by putting the borrower on a 'short leash'. Maturity may act as an especially important tool for banks operating in these environments because shortening loan duration mitigates risk even absent a well-functioning legal regime (e.g., Diamond, 2004).

Third, our empirical work illustrates how loan ownership structure interacts with price and non-price loan contract terms. For example, we find that decreased loan concentration (i.e. more banks participating in a loan) comes with a greater likelihood that collateral is used. Diffuse loan ownership - which again may reduce strategic defaults - may therefore complement collateral as a mechanism to solve borrower control problems. As noted above, we find that the share of loans owned by domestic banks increases with legal formalism due to their ability to restructure loans

\footnotetext{
${ }^{5}$ Using similar data sets like ours, Bae and Ghoyal (2004) link loan interest rates (only) to cross country legal and institutional variables. They find no effect of creditor rights (combining ability to take collateral and oust management) on loan rates, similar to our results. They do not, however, split the creditor rights variable into two components, as we do. Also, they do find a negative relationship between property rights and interest rates on loans, based on loans made to Asian countries, in which interest rates on loans are not based on a markup over LIBOR rates as loans from other regions are priced. We drop Asian loans in our interest rate regressions because the rates are not comparable to the spreads from other regions in Dealscan.
} 
privately. In addition, interest rates decline with the participation of domestic banks, perhaps suggesting their better ability to assess borrower risk and perhaps solve control problems than foreign banks. Esty (2004) finds similar results with a sample of project finance loans.

The rest of the paper is organized as follows. In Section II, we review related strands of literature on the forces that shape bank loan contracts across different borrower countries, and we describe our key legal and institutional variables. In Section III, we describe our sample of bank loans around the globe, and then present the main empirical results. Section IV concludes the paper. The Appendix contains explanations of all the variables that we use in the paper.

\section{Financial Contracts, Legal Protection, and Institutions}

In this section we briefly review related strands of literature on law, finance, institutions, and financial contracting between business counterparties. We then use these theoretical arguments to motivate our empirical model.

Our point of departure is the now well-established set of links between legal and institutional variables and financial-system "outcomes" measured at the country level. LLSV (1997, 1998) differentiate countries with legal systems derived from those in England, France, Germany and Scandinavia. In addition to these four legal origins, LLSV also characterize another group of countries as having "socialist origin" - the countries that have evolved from socialist, centrally planned economies to market-based economies. LLSV find that countries with English common-law and French civil-law origins are at the extremes. For example, relative to the French legal-origin countries, the English common-law countries have larger financial systems as a share of GDP, they have bigger securities markets, more IPOs, more diffuse ownership of public equity, higher Tobin's Q, and higher dividend payouts that are more closely tied to profits. In addition, the English group of countries offers stronger legal protection of shareholders and creditors, and they have more efficient courts and judicial systems. Not surprisingly, countries with socialist 
origin are much closer to French-origin countries than to English-origin countries in terms of their legal and financial systems.

Before describing our approach in detail, it is worth briefly describing the "Coasian view" (Coase, 1937, 1960) that private parties, absent significant transaction costs, can reach an optimal contract - or move toward an optimal contract - even when certain aspects of the contract are not specified in the law. At first blush, the strong link between a country's laws/institutions and the fitness of its financial system undercuts, to some degree, the Coasian logic. That is, if transactions costs were low enough and all contracts enforceable, then all positive NPV investments would be financed - no financial system would have "better" outcomes than any other. The Coasian logic dictates that financial counterparties living in systems with "weak" institutions will find clever ways to offset, or partially offset, the limitation and weakness of those institutions. Applied to the case of bank loan contracts, for example, lenders might seek extra protection beyond what is provided by the legal system through bargaining. The final contract might include protection clauses not provided by law upon agreement from both the lender and borrower, so long as the costs of writing and enforcing these clauses are lower than the benefits of adding them. Even if the 'Coase Theorem' held exactly, we might still be able to observe differences in the terms of contracts. Thus, our empirical strategy will help illustrate how financial counterparties attempt to offset the costs of contracting in a country with weak laws/institutions.

Despite the work of LLSV and others, we still know very little about how, exactly, these legal and institutional variables affect specific aspects of the financial contracts themselves (as opposed to outcomes like the size of equity or debt markets relative to GDP). Our aim is thus to test directly how differences in the contracting environment affect the specific terms of bank loans to large corporate borrowers. 
We consider two sets of explanatory variables that will affect the design of bank loans. The first set of variables incorporate micro-level aspects of the loan, the borrower, and the lender. These measures have been employed widely in the bank loan literature and, for our purposes, should be thought of as control variables. For example, larger borrowers and borrowers with highly rated debt pay lower interest rates and are more likely to be able to borrow on an unsecured basis relative to smaller and less well-rated borrowers (Strahan, 1999).

The second set of variables describes the country-level factors. These include: (1) variables capturing basic legal protections (creditor rights, property rights, and the risk of government corruption); (2) the functioning of the courts (legal formalism); (3) legal origin; and (4) development (both financial and economic). ${ }^{6}$ These country-level differences are the focus of the paper. Taken together they measure how well a country enforces contracts and protects investors in practice. While creditor and property rights specify the basic legal protections, the efficiency of the courts can be thought of as a proxy for the transaction costs in the implementation of these legal protections, in that the actual protection of creditors can be weak in a country despite comprehensive protections provided by law due to the costly implementation process.

In the remainder of this section, we describe the variables and briefly review why each may affect the design of bank loans. It is reasonable to assume that certain aspects of law and institutions will have first-order impact, while others will probably be less important. We examine those aspects of the legal system and a country's institutions that we view as potentially being most important. For other aspects of the law, whose impact we cannot measure directly, we include the legal-origin dummy variables, as in LLSV.

\footnotetext{
${ }^{6}$ Country-level factors also include measures on a country's macro-economic condition, including business cycles, but this is not the focus of our paper.
} 


\section{Creditor Rights}

Creditor rights are of paramount importance for lenders in determining their basic legal protections against borrower expropriation. We start with a single index to measure a borrower country's overall creditor rights. The index, developed in LLSV's "Law and Finance" (1998) paper, begins at zero and adds one for each of the following conditions that hold: (1) secured creditors gain possession of assets once the petition for reorganization receives approval (i.e. there is no automatic stay on creditors' ability to seize collateral); (2) secured creditors are ranked first in the distribution of proceeds; (3) there are restrictions such as creditors' consent for going into reorganization; and, (4) management does not stay in control of the firm during the reorganization. A higher score indicates stronger creditor rights. This index is available for about 100 countries from the World Bank.

We use these conditions to develop two additional indices. The first focuses on conditions (1) and (2), which specify ways that managers can prevent secured lenders from getting paid in full when the firm is in financial distress. Thus, a higher score (from 0 to 2 ) indicates stronger creditors' ability to seize collateral under default/distress scenario. Clearly the utility of collateral, both as a control mechanism and as a tool to reduce loss given default, increases with the index by making it easier for lenders to take (or threaten to take) control of assets. ${ }^{7}$ Thus, we would expect stronger creditor rights to be associated both with greater use of collateral (a cost to borrowers) but lower interest rates (a benefit). The second index keys on the last two categories of the index above, indicating what the borrower firm's managers can do to remain in control of the firm's

\footnotetext{
${ }^{7}$ Our results linking the law of the borrower's country to loan terms will, if anything, understate the true impact of law for most small and domestic borrowers. Most of our data are syndicated loans, which is a market dominated by large multinational banks serving large borrowers. Many of these loans are arranged and negotiated in either London or New York, and the loan contracts often include a "choice of law" clause that allows the law of the U.S. or U.K. to supercede the laws in the borrower's country. However, local insolvency laws often override these clauses in the event of default (Esty and Megginson, 2002; Norton, 1997). Thus, to the extent that attempts to export U.S. or U.K. law succeed in non-default states, our results will tend to be attenuated.
} 
assets despite poor firm performance. With a higher score (0 to 2), creditors have stronger ability to oust management during reorganization following poor performance. ${ }^{8}$ Because we need the disaggregated information on bankruptcy law to compute these two sub-indices, we lose a significant number of countries. Hence, we report our results first using the broad creditor rights index, and then using the two sub-indices.

\section{Property Rights}

While creditor rights specify lenders' ability to control defaulting borrowers, our property rights measure examines more broadly the extent to which the government and law protect private property generally. The property rights measure is an index ranging from 0 to 5 , with a higher score indicating better protection of private properties, from the Index of Economic Freedom (IEF), published by the Heritage Foundation. The index measures the degree to which private property rights are protected and accounts for the possibility that such property will be expropriated. In addition, it analyzes the independence of the judiciary, the existence of corruption within the judiciary, and the ability if individuals and businesses to enforce contracts. ${ }^{9}$

\section{Government Corruption}

To measure government corruption, we follow LLSV $(1998,1999)$ and use data from the International Country Risk Guide (ICRG hereafter). ${ }^{10}$ This measure, similar to the property rights

\footnotetext{
${ }^{8}$ It is also important to point out that the creditor rights index is constructed based on whether the protection of creditors' rights (along one of the four dimensions) is provided by the borrower country's law. All the other countrylevel variables (property rights, corruption, and legal formalism) are constructed based on surveys, and thus may contain more measurement error.

${ }^{9}$ For a list of variables considered for the index, see Appendix A.1. In compiling the index, the authors of IEF utilize sources from Economist Intelligence Unit, ILT Report, 1999; U.S. Department of Commerce, National Trade Data Bank of the U.S. and Country Commercial Guides; U.S. Department of State, Country Reports on Human Rights Practices for 1998; and World Bank, Country Briefs, 1998.

${ }^{10}$ The ICRG (of the PRS Group, Inc.) rating for each of the more than 120 countries comprises 22 variables in 3 categories of country risk, political (including corruption), financial, and economic, based on which a composite country risk measure is constructed. Details are available at http://www.icrgonline.com/.
} 
measure, is part of ICRG's "political risk" composite index. The variable ranges from 0 to 10 , with lower scores indicating that "high government officials are likely to demand special payments and illegal payments are generally expected throughout lower levels of government." Unlike ICRG's financial and economic indices, which are based on mostly statistical models and data, the corruption index (as well as other political risk measures) is assessed based on ICRG staff”s subjective analysis of "qualitative” political information.

Both the property rights and the corruption indices measure the risk of expropriation from the government or powerful elites of a country. In contrast, the other variables in our model, such as the creditor rights index and the institutional variables described below, measure the risk of expropriation from individuals or firms, which are typically the counterparty to the contract. With country-level evidence, Acemoglu and Johnson (2003) argue that expropriation by government and elites hinders financial system development and overall economic growth because individuals cannot contract around this type of risk. In particular, standard tools used to offset credit risk, such as collateral in a bank loan contract, may be less effective in mitigating the risk of expropriation from government or elites. In contrast, shortening the maturity of the contract may be a more robust tool to handle such risk. By comparing the impact of government corruption with the impact of the other law and institution variables on bank loan contracts, we can draw inference on the relative importance of these two kinds of risks.

\section{Legal Formalism}

Legal formalism measures how efficiently the courts of the borrower's country enforce contracts (DLLS, 2003). Court efficiency matters because lenders' ability to enforce or threaten to enforce specific aspects of a loan contract (e.g. covenants) or take away collateral will depend on the costs of using the legal system. Court efficiency may also matter more broadly for the 
borrower as an indicator of how costly it is to enforce contracts beyond the loan agreement (e.g. contracts with suppliers, workers, etc.) Based on extensive surveys of Lex Mundi/Lex Africa association of law firms, DLLS have constructed measures based on how courts handle two types of cases: Collection of a bounced check, and eviction of a (non-paying) tenant, with a higher score in either category implying that the court system is slower (with more bureaucracy) and less efficient. ${ }^{11}$ These measures are highly positively correlated across countries, and we choose to use the check-based formalism index for our study as the process of collecting a check through a court is more closely related to creditors' desire of collecting their investment back from the borrowers (although other contracts matter to the borrower too).

With more legal formalism (i.e. a higher score on the index) in a borrower country, it takes longer for lenders to collect money or assets from a borrower. In anticipation of this, lenders may shorten the length of the loan and "put the borrower on a short leash." Alternatively, with more efficient courts, it becomes easier (and quicker) for lenders to seize control of the firm's assets from the firm's managers when they are allowed to do so. Thus more efficient courts can actually lower borrowers' bargaining power when negotiating with the lenders.

\section{Residual Impact of Legal Origin and Financial Development}

As discussed above, there are potentially other aspects of legal protection and institutional efficiency that we do not consider but can affect the design of loans. Since LLSV have demonstrated that almost all of these variables are highly correlated with indicators of legal origin, we include these legal origin indicators to proxy for possible omitted variables. We also control

\footnotetext{
${ }^{11}$ DLLS sent questionnaires to law firms around the globe, which cover the step-by-step evolution of an eviction and a check collection before local courts in 115 countries' largest cities. The questions are divided into two parts: 1) description of the procedure of the hypothetical case, including estimates of the actual duration at each stage, whether written submissions are required, specific laws applicable, the form of appeal, the existence of alternative administrative procedures; 2) multiple choice questions are used to collect additional information. See Appendix A.2 for the seven categories of legal formalism.
} 
for economic and financial development in most of our empirical models. Financial development equals the ratio of total private domestic bank credit to GDP, averaged over the 1994 to 1997 period; ${ }^{12}$ economic development equals the log of GDP per capita, averaged over the 1994 to 2002 period.

\section{Empirical Methods \& Results}

\section{III.1 Data}

We build a sample of bank loans made to large borrowers located in almost 60 countries (excluding the U.S.). Loan information comes from the Loan Pricing Corporation's Dealscan database, which provides detailed coverage of bank lending to large corporations. The dataset dates back to the late 1980s, but coverage of lending to companies outside the U.S. was quite sparse until the middle of the 1990s. Hence, we begin our sample with loans originated in 1994 and include loans originated through the middle of 2003.

Dealscan allows us to identify which banks are lending to which firms in each year, and to observe in detail various terms of the loans at origination, including the interest rate (measured as a basis point spread over LIBOR, inclusive of all fees), whether or not the loan is secured, the maturity of the loan, the number of lenders involved (many of the loans are syndicated), as well as the identity of the borrower and lender. From these last two pieces of information, we construct the share of the loan held (at origination) by banks located in the same country as the borrower, and the share held by banks controlled by governments (although not necessarily the borrower's government). ${ }^{13}$ These ownership and contract features serve as the basis for the dependent

\footnotetext{
${ }^{12}$ We obtain times series data for all countries from Demirgüç-Kunt and Levine (2002), which does not provide data on financial development after 1997.

${ }^{13}$ Information is based on the Bankscope database. Banks are considered government controlled if more than $25 \%$ of the shares are owned by governments. The home country of a bank is based on the location of the bank holding company. For example, Citibank's affiliate operating in India is classified as a U.S. bank.
} 
variables in our models. The qualitative variable is coded as follows: The secured lending indicator equals one if the loan is secured and zero if it is not. For this model, we estimate a Probit and report marginal effects (rather than Probit coefficients). Thus, the reported coefficients represent the change in the probability per unit change in the relevant explanatory variables. (For indicator variables, the coefficient represents the change in the probability associated with moving the indicator from 0 to 1.) The other models are estimated with OLS, where the dependent variable equals the log of the number of lenders, the percent of the loan held by government banks (ranging from 0 to 100), the percent held by domestic banks (0 to 100), the log of the loan maturity (in months), and the log of the basis point spread of the loan interest rate over LIBOR.

Beyond these loan contract terms, Dealscan also includes information on the type of loan (e.g. lines of credit versus term loans), the purpose of the loan (e.g. debt repayment, commercial paper backup line of credit, general corporate purpose, etc), and the size of the loan. ${ }^{14}$ We control in our model for loan type and loan purpose with indicator variables, and we control for loan size by including the log of the commitment amount (in U.S. dollars). ${ }^{15}$ We also include an indicator variable equal to one for loans denominated in one of the following major currencies: U.S. dollars, Euros, German DM, British pounds, or Japanese Yen.

For borrower characteristics, Dealscan contains information on Moody's and S\&P senior debt rating at the close of the loan, which we include to control for borrower risk. We use the Moody's rating unless it is missing, in which case we use S\&P, while unrated firms constitute the omitted category. We include an indicator for multinational firms, and a set of 1-digit SIC

\footnotetext{
${ }^{14}$ The Dealscan data allow us to observe the commitment amount at origination, but not the amount of funds actually taken down by the borrower.

${ }^{15}$ Any effects of inflation are absorbed by year fixed effects.
} 
indicator variables. ${ }^{16}$ We also drop loans to firms in SIC 4 (utilities), 6 (financials) and 9 (public sector) because firms in these sectors are more apt to be government owned or government protected monopolies; hence, the risks of these kinds of firms may be very different from manufacturing and trade firms. Dealscan has only very sparse information on borrower sales, but by including the size of the loan in the models we are able to absorb the bulk of differences based on borrower size.

Given the selection of banks and firms in Dealscan databases, we acknowledge that the results will reflect the effects of cross-country differences in law and institutions on financial contracting between large banks and large borrowers. To some extent focusing on these data limits the generality of our findings, but we think that loans to smaller borrowers are likely to be shaped significantly by a set of social, cultural and relationship variables that would be difficult or impossible to observe and control across a large number of countries (Petersen and Rajan, 1994). In our view, individual country-level studies, rather than cross-country comparisons, would offer a more fruitful way to understand financial contracting for small firms. ${ }^{17}$

Table 1 reports summary statistics on the loan terms by the legal origin of the borrower country. The loans are of similar size on average in the five country groups, ranging from $\$ 133$ to \$224 million. Pricing appears similar in the English, French, German and Scandinavian legalorigin countries, with a mean spread over LIBOR ranging from 164 to 180 basis points. In contrast, loan spreads are considerably higher in the formerly Socialist countries (230 bps). These large pricing differences likely reflect, at least in part, the differences in average borrower risk for this latter group. For the non-price contract terms, the share of loans that are secured ranges from

\footnotetext{
${ }^{16}$ A company is defined to be multinational if its parent and the company itself operate in different countries.

${ }^{17}$ For example, Allen, Qian, and Qian (2004) show that the private sector in China, despite poor legal protections and inadequate financing through standard channels, has been growing very fast, relying on alternative governance mechanisms and financing channels such as reputation and relationships.
} 
a low of 27 percent (in the German countries) to a high of 75 percent (in the Scandinavian countries). Note that this variable is missing for about $1 / 2$ of our sample. Average maturity ranges from 50 to 72 months across the groups.

Ownership also varies considerably across country groups. For example, government ownership of our sample of loans is highest in the formerly Socialist countries (22 percent) and the Scandinavian countries (12 percent). The percentage of loans held by domestic banks is by far the lowest in the Socialist countries, presumably because of the relatively low level of financial development in these countries. In contrast, in the German legal-origin countries, domestic bank ownership of loans predominates (71 percent).

\section{III.2 Regression Models}

In our regression models, we begin by testing in reduced form the effects of country-level variables on ownership of loans and the price and non-price terms of these loans. We then consider how the ownership variables interact with the contract terms in our last set of results. These latter regressions cannot be viewed as pure reduced forms because the ownership and contract terms may be determined jointly. Thus, it is difficult to determine the causal links between the two. Nevertheless, we think these results help illustrate the extent to which ownership affects banks' ability to enforce loan contract terms. Last, we report all of our models separately for rated and unrated borrowers.

We control for borrower characteristics with six ratings indicators (AAA, AA, A, BBB, $\mathrm{BB}$, and B or worse) and six one-digit SIC industry indicators; we also control for loan characteristics with a full set of loan purpose indicators, log of loan size, and an indicator for lines of credit. We also include indicators for legal origin, with the English legal-origin countries serving as the omitted category. To control for business cycle conditions, the models include year fixed effects and the growth rate in GDP (in \$s) during the year in which the loan was originated. 
To control for the level of economic and financial development, we include the log of per-capita income in the country and the ratio of private bank credit to GDP. And, we include the variables testing how specific aspects of the financial contracting environment affect ownership and loan terms, as described in Section II above.

Table 2 reports mean values for the country-level variables across the five legal-origin groupings. Consistent with the earlier research of LLSV, countries with French or Socialist legal origins tend to have weak protection of creditor \& property rights, and their courts tend to have a high degree of legal formalism. In addition, government corruption seems higher in these countries relative to the German or Scandinavian legal-origin countries. Because we have many loans for each country (compare the number of observations in Tables 1 and 2), but no variation on our key explanatory variables within countries, we cluster the error across all loans made in a single country to account for possible dependence in the error. ${ }^{18}$

Tables 4-6 report the main regression results, while Tables 7-9 then reproduce these results after separating the data based on whether or not the borrower has a credit rating. Table 4 focuses on reduced form models of ownership, and Table 5 on reduced form models of the price and nonprice terms of loans. In Table 6, we introduce the ownership variables as right-hand side variables in the regressions for loan terms.

\section{III.3 Unobserved Heterogeneity}

Before describing these results, it is worth acknowledging the potential problem of unobserved firm-level heterogeneity. As noted, we $d o$ attempt to control for borrower attributes by including loan size, ratings indicators, and industry indicators in our regressions; but lenders clearly have access to more information than that, and they may use their additional information to

\footnotetext{
${ }^{18}$ For example, measurement error in a county-level legal or institutional variable would induce correlation in the model error across all loans to borrowers living in that country.
} 
set loan terms. Therefore, there is the possibility that omitted firm-level characteristics may bias our results.

We deal with this problem in two ways. First, we have obtained a sample of borrowerlevel observable characteristics by manually matching Dealscan loan data with annual reports from the Worldscope database. In Table 3, we report the correlation between firm size (log of market capitalization), profits (net income divided by book value of assets) and leverage (total debt to assets) and our legal and institutional variables for this sub-sample. These correlations are very low and not statistically significant, with the exception that the log of (firm) market value is positively correlated with the corruption index $(\rho=0.33)$. Consequently, other than corruption there seems to be little room for omitted firm attributes to bias our coefficients of interest.

As a second test, we report our results in Tables 4-6 with and without those firm-level variables that we can observe. This second approach is especially important given that firm size and corruption are found to be correlated. If omitting observable dimensions of firm risk (which includes firm size as proxied by loan size) does not change the coefficients of interest, it seems implausible to us that omitting unobservable dimensions will create an important source of bias. As it turns out, our results are robust to the exclusion of these control variables.

\section{III.4 Results}

\section{Ownership}

The concentration of ownership of bank loans seems to be higher - that is, the number of lenders is lower - in countries that are better developed economically (Table 4, columns 1 and 2). Moreover, as found in Ongena and Smith (2000), better protection of creditor rights is associated with fewer lenders (marginally significant). These results suggest that diversification - spreading a syndicated loan across many lenders - is one of the tools that banks can use to mitigate legal, 
institutional and other non-business risks. We also find, as do Ongena and Smith (2000) and Esty and Megginson (2003), that ownership concentration is significantly lower in the civil law countries (French and German legal origin), controlling for the observable legal and institutional variables. Esty and Megginson argue that lenders attempt to forestall strategic default in countries where creditor rights are weak through diffuse ownership, which could also explain our findings. ${ }^{19}$ While there may be validity to this argument, better protection of property rights and lower levels of government corruption seem to come with more, rather than fewer, lenders. These dimensions of country risk may be better dealt with by concentrating the loan amongst banks that understand political or government expropriation risk, rather than through diversification.

The share of loans held by government banks is lower in better-developed economies, and, controlling for observables, is much higher in the formerly Socialist countries and Scandinavian countries (Table 4, columns 3 and 4). We conversely find that the share of loans held by domestic banks is much lower in the Socialist and Scandinavian countries (columns 5 and 6). For financial development, we find a much higher share of loans held by domestic banks, although this finding is true almost by definition because our measure of financial development is based on the size of the domestic banking system (relative to GDP).

We also find that legal formalism is associated with much greater holdings of loans by domestic banks. The effect is large economically as well as statistically. For example, a standard deviation increase in legal formalism (an increase of 1.1) comes with an increase in the share held by domestic banks of about 10 percent of the loan. Mian (2004) shows that foreign lenders are more likely than domestic lenders to resolve defaulted loans in a formal court procedure. $\mathrm{He}$ argues that foreign lenders are less able to establish long-term relationship capital with borrowers

\footnotetext{
${ }^{19}$ See Bolton and Scharfstein (1996) and Diamond (2004) for theories explaining why diffusion of ownership can reduce the possibility of strategic default, and Sufi (2004) for empirical evidence on U.S. firms and banks.
} 
and exploit this relationship during private workouts, thus they resort to formal legal procedures. If the cost of using courts increases with legal formalism (as argued by DLLS), then our results would support Mian's conclusions, as foreign lenders will be less willing to lend where court procedures are slow and cumbersome. ${ }^{20}$

\section{Contract Terms}

Table 5 reports reduced form results for the loan contract terms. As noted, we use two specifications for the creditor rights index. The index in Panel A of Table 5 includes all four conditions of creditor protection described in Section II, and ranges from 0 to 4. In Panel B the overall creditor index is split into two: The first (ranging from 0 to 2) indicates creditors' ability to oust management during reorganization, while the second (also ranging from 0 to 2 ) indicates their ability to seize collateral under a default/distress scenario (i.e. secured creditors gain possession of assets once the petition for reorganization receives approval, and secured creditors are ranked first in the distribution of proceeds). ${ }^{21}$

We first find that collateral is significantly more common in countries with stronger creditor rights (columns 1 and 2 of Panel A). From Panel B (columns 1 and 2), we see that this result is driven by creditors' rights to seize collateral, while their ability to oust management does not have much impact on any of the three contract terms. Our result thus reflects a kind of 'Coasian' bargaining whereby a contracting tool (collateral) is used more where courts are more willing to enforce its terms. This effect is large economically as well as statistically. For example, the coefficient in Panel B suggests that a borrower in Mexico (index on creditors' rights to seize

\footnotetext{
${ }^{20}$ We also show in Table 4 that in countries where financial markets are better developed, the domestic ownership share is higher. This result, however, is difficult to interpret because of an obvious and mechanical reverse causality. We include it for consistency with the other results, but the other coefficients in the model are not sensitive to the exclusion of this variable.

${ }^{21}$ The sample size is smaller in Panel B than that in Panel A, because the split creditor rights indexes are available for only 49 countries from the LLSV (1998) paper.
} 
collateral $=0$ ) would be 25 percent less likely to post collateral compared to a similar borrower in the U.K. (index on creditors' rights to seize collateral =2). The same Coasian bargaining argument can also explain the positive relation between economic and financial development and secured lending (positive and significant in Panel A; still positive but not significant in Panel B). In developed countries, lenders have access to liquid financial markets to sell collateral if necessary, making secured lending a more effective contracting tool.

We also find greater use of collateral in countries with more legal formalism, and where there is a higher risk of government expropriation (i.e. weak property rights), although these results are again weaker in Panel B. The coefficient on property rights protection in Panel A implies that a standard deviation increase in property rights protection comes with about a 15 percentage-point decline in the probability that a loan is secured.

The maturity of banks loans also appears to be shaped by the contracting environment (Table 5, columns 3 and 4 in Panels A and B). We find that stronger creditor rights, in particular creditors' ability to seize collateral, are associated with longer term lending, and the coefficient is again large economically. From Panel B and using the example from above, the coefficient on creditors' ability to take collateral suggests that loan maturity would be about 25 percent longer in the U.K. compared to Mexico. We also find that increased risk of corruption or expropriation of property by governments is associated with shorter term lending.

Somewhat to our surprise, we find a positive link from legal formalism to loan maturity. One potential explanation may be that legal formalism acts as a broader measure of contracting costs beyond just the ex-post enforcement costs associated with adjudicating a dispute in the courts. Thus, writing longer-term contracts (increasing loan maturity) may help minimize costs by reducing the likelihood of rewriting contracts and enforcing them through courts. The greater use 
of collateral in countries where legal formalism is high may be the means by which lenders protect themselves against the greater risk of lending long term. ${ }^{22}$

In the last two columns of Table 5, we test how the pricing of loans reflects the countrylevel legal and institutional variables. ${ }^{23}$ We find almost no impact of any of the legal or institutional variables on the loan interest rate except for creditors' rights/ability to seize collateral. This suggests that the contracting tools emphasized above - ownership, collateral and maturity seem to be affected more by the contracting environment than the price. This non-result, we argue, is quite striking given the strong links found with non-price terms of loans. Recall that where government risk is high, banks loans tend to be secured and they tend to have shorter maturity. The fact that we find no effect of government risk on loan prices suggests that these non-price contracting tools allow banks to control this risk effectively. This does not mean that borrowers face no costs of operating where government expropriation is more likely, because collateral is costly for them. However, it reflects a kind of "Coasian" effect whereby contracting can help offset, if not fully remove, some of the impediments to investment from poor institutions.

While institutional variables do not affect interest rates, creditors' ability to take collateral in default does have a significant impact on the cost of capital. From Table 5 Panel B, and using the same example one more time, interest rate spreads on loans are about $38 \%$ higher in Mexico compared to the U.K. Taken with our earlier results, we can now describe how creditor rights regarding their ability to take collateral shape loan contracts, a central result of our paper: With strong rights, creditors concentrate their holdings, are more apt to use collateral, lend on a long-

\footnotetext{
${ }^{22}$ The results on loan maturity are robust when we re-run the regressions by 1-digit SIC of borrowers. For example, creditor rights and legal formalism both enter positively and significant in six out of seven segments (negative but insignificant for 1 segment).

${ }^{23}$ Since most of the loans in the sample are float-rate loans and the interest rates are measured by the mark-up over LIBOR, term-structure factors should not affect our results. As mentioned above, since interest rates on loans made to Asian countries are structured differently, we drop Asian loans in our interest rate regressions.
} 
term basis, and charge lower rates. How do lenders cope with weak legal protection, where collateral is less useful to control borrowers? Our results suggest that loan ownership concentration is reduced (thus reducing the strategic default problem and facilitating diversification of risk across lenders), maturity is shortened (thus effectively putting borrowers on a short leash), and interest rate is higher (thus pricing for the possible losses in default). ${ }^{24}$ Finally, from Panel B we can see that the other dimension of the creditor rights, i.e., their ability to oust management, does not seem to affect any of the loan contract terms. The difference between the two dimensions of creditor rights may stem from the fact that in our sample of syndicated loans, foreign banks, which play leading roles in the syndicate, should be much more concerned about whether they can take and sell loan collateral than oust an incompetent manager in countries with very different institutional and economic background from their own.

In Table 6, we add the ownership terms as right-hand-side variables in the loan contract regressions. Adding loan ownership has little effect on the links from the legal and institutional variables to the loan terms. However, ownership itself $i$ s significantly correlated with collateral and pricing of loans. For example, loan concentration is strongly associated with collateral, whereas the participation of domestic banks is strongly related to pricing. Loans with a greater number of participating banks are more likely to be secured. A one standard deviation increase in the number of participating banks increases the probability that a loan is secured by about 7 percentage points. This suggests a complementarity between two control mechanisms: collateral (to raise the direct cost associated with default to borrowers) along with diffuse ownership (to raise the deadweight costs associated with default, thus preventing strategic default).

\footnotetext{
${ }^{24}$ There are additional tools for lenders to overcome poor protection of creditor rights. For example, Siegel (2004) shows that Mexican firms that cross list in New York (voluntarily) follow U.S. securities laws and protect investors beyond what is required in Mexico. Jappelli and Pagano (2002) examine private credit bureaus and public credit registers and find that better information sharing leads to more bank lending and lower defaults.
} 
Participation in a loan by domestic banks is also very strongly correlated with the loan interest rate. ${ }^{25}$ A standard deviation increase in this percentage (41 percentage points) comes with an eight to 12 percent reduction in the loan interest rate (the all-in spread). This decline suggests that domestic banks have an advantage relative to foreign banks in overcoming information and control problems. With asymmetric information, uninformed foreign banks may require higher loan interest rates when relatively well-informed domestic banks are unwilling to fund a significant portion of the deal. ${ }^{26}$ According to this adverse selection explanation, most opaque borrowers will be served by domestic banks to avoid paying this 'lemons' discount. And, there is some evidence for this allocation of borrowers to banks in our results. For example, the models in Table 4, where we explain domestic bank ownership share with country and borrower characteristics, suggest that rated firms (i.e. transparent firms) are more likely to be served by foreign banks. The share of loans held by local banks is 11 percentage points lower for B-rated firms relative to unrated firms (coefficients not reported in Table 4). ${ }^{27}$ Mian (2004) finds similar patterns in Pakistan.

\footnotetext{
${ }^{25} \mathrm{We}$ also find a negative relation between shares held by government banks and interest rates, although this result is not statistically significant. LLS (2002) find that government ownership of banks slows down economic growth, while Sapienza (2004) finds that state-owned banks in Italy charge lower interest rates to firms with political connections with the banks.

${ }^{26}$ However, since we only observe contract terms at the loan closing date, we cannot compare the subsequent performance of the loans. La Porta et al. (2003) examine related lending in Mexico (banks lend to firms controlled by banks' owners) and find that related loans have lower interest rates, are less likely to post collateral, more likely to default and have lower recovery rates, compared to unrelated ones.

${ }^{27}$ In fact, relative to unrated firms, the percentage held by domestic banks is 13 points lower for AAA rated firms, 3 points lower for AA rated firms, 8 points lower for A rated firms, 13 points lower for BBB rated firms, 14 points lower for BB rated firms, and 11 points lower for firms with $\mathrm{B}$ rating or below.
} 


\section{Rated v. Unrated Borrowers}

Tables 7 through 9 report the same set of regressions for rated and unrated borrowers. ${ }^{28}$ These results suggest that the effects of most of the legal variables are greater for the unrated firms than for rated firms. For example, creditor rights are not related to ownership concentration (column 2, Table 7) or maturity (column 4, Tables 8 and 9) for the rated borrowers. Similarly, legal formalism is strongly related to loan maturity (column 3, Tables 8 and 9) only for the unrated borrowers. $^{29}$ This makes sense because large and rated companies may have greater freedom than unrated companies to move their financial business around the world and thus find favorable contracting environments. In contrast, government risk appears to affect loan ownership (Table 7) to both rated and unrated firms.

We also find two interesting difference across these sets of borrowers, both related to legal formalism. First, formalism is positively related to the domestic ownership share to unrated firms but negatively related to the domestic share for rated borrowers (columns 5 and 6, Table 7). Thus, foreign lenders seem to avoid lending to unrated and presumably relatively opaque firms in countries where legal formalism is high. Our interpretation of this result is that domestic lenders have an especially big comparative advantage for unrated borrowers where legal formalism is high. The reason is that local banks have the ability to restructure loans without access to the legal system, whereas foreign lenders do not have this ability (Mian, 2004). The fact that foreign lenders hold a greater share of loans to rated borrowers where legal formalism is high indicates some substitution away from domestic banks for larger and rated firms in countries where the domestic banking system specializes in lending to unrated firms. Second, the interest rate on loans

\footnotetext{
${ }^{28}$ We do not have enough observations on collateral to estimate the probit model for the rated firms alone. Results for unrated loans are not sensitive to dropping firm control variables used in Tables 4 through 6.

${ }^{29}$ However, separating the sample into secured and unsecured lending does not change the positive link from legal formalism to maturity.
} 
to rated borrowers increases with legal formalism, but interest rates are unrelated to formalism for unrated borrowers (columns 5 and 6, Tables 8 and 9). In contrast to unrated borrowers (served by local banks), rated borrowers bear the cost of the legal system because their foreign lenders have to rely on the courts to collect on bad loans.

\section{Conclusions}

In this paper we examine how legal origin, creditor and property rights, the quality of the courts, and economic and financial development affect the design of bank loan contracts across a wide cross section of countries. Our results support the law and finance view that private contracts reflect differences in legal protection of creditors and properties, as well as the cost of writing and enforcing contracts. In particular, we find that secured lending is less common in countries with undeveloped financial markets and weak protection of creditor rights. At the same time, weak protection of creditor rights, in particular creditors' rights to seize collateral, comes with greater diffusion of loan ownership, shorter term lending, and higher interest rates. Thus, we can begin to paint a clearer picture of why creditor rights are important in generating good financial outcomes. With them, lenders can control borrowers with collateral because they know they will be able to take assets, or credibly threaten to take assets, ex post in default. Collateral is probably even more useful where economic and financial development allows assets to be liquidated, as we find more secured lending in countries with higher income per capita. In contrast, lenders resort to diffuse ownership, short maturity, and higher interest rates to control borrowers in countries where creditor rights are weak.

Our results also suggest that contracting costs, as measured by legal formalism, shape the terms of bank loans. Where legal formalism is high, domestic banks are the main lender to unrated firms. In these environments, loan maturity tends to be longer (to reduce contracting 
costs) while the use of collateral tends to be more common (to reduce risk). We do not find, however, that interest rates reflect legal formalism for unrated borrowers. For rated borrowers, legal formalism is associated with a greater role of foreign banks. For these borrowers, interest rates do increase significantly with legal formalism. This pricing relationship, we argue, reflects foreign banks' greater reliance on the legal system to collect on defaulted loans.

As a final caveat, we only explore empirically the terms of loans actually made; borrower access to credit may be limited where property rights and corruption are most problematic. Studying credit access may require more detailed firm-level data than is currently available across a wide range of countries. 


\section{Appendix: Brief Descriptions of All the Variables and Their Sources}

\section{A.1. Legal Variables}

\begin{tabular}{|c|c|c|}
\hline Variables & Description & Sources \\
\hline Legal Origin & $\begin{array}{l}\text { Identifies the legal origin of the company law or commercial code of } \\
\text { each country }\end{array}$ & $\begin{array}{l}\text { Reynolds and Flores } \\
(1989), \text { LLSV (1998) }\end{array}$ \\
\hline $\begin{array}{l}\text { Restrictions for } \\
\text { going into } \\
\text { reorganization }\end{array}$ & $\begin{array}{l}\text { Equals } 1 \text { if the reorganization procedure imposes restrictions, such as } \\
\text { creditors consent; it equals } 0 \text { otherwise }\end{array}$ & $\begin{array}{l}\text { Bankruptcy and } \\
\text { reorganization laws; } \\
\text { LLSV (1998) }\end{array}$ \\
\hline $\begin{array}{l}\text { No automatic stay } \\
\text { on secured assets }\end{array}$ & $\begin{array}{l}\text { Equals } 1 \text { if the reorganization procedure does not impose an } \\
\text { automatic stay on the assets of the firm on filing the reorganization } \\
\text { petition. Automatic stay prevents secured creditors from gaining } \\
\text { possession of their security. It equals zero if such a restriction does } \\
\text { exist in the law }\end{array}$ & $\begin{array}{l}\text { Bankruptcy and } \\
\text { reorganization laws; } \\
\text { LLSV (1998) }\end{array}$ \\
\hline $\begin{array}{l}\text { Secured creditors } \\
\text { first }\end{array}$ & $\begin{array}{l}\text { Equals } 1 \text { if secured creditors are ranked first in the distribution of the } \\
\text { proceeds that result from the disposition of the assets of a bankrupt } \\
\text { firm. Equals zero if nonsecured creditors, such as the government and } \\
\text { workers, are given absolute priority }\end{array}$ & $\begin{array}{l}\text { Bankruptcy and } \\
\text { reorganization laws; } \\
\text { LLSV (1998) }\end{array}$ \\
\hline $\begin{array}{l}\text { Management does } \\
\text { not stay }\end{array}$ & $\begin{array}{l}\text { Equals } 1 \text { when an official appointed by the court, or by the creditors, } \\
\text { is responsible for the operation of the business during reorganization. } \\
\text { Equivalently, this variable equals one if the debtor does not keep the } \\
\text { administration of its property pending the resolution of the } \\
\text { reorganization process. Equals zero otherwise }\end{array}$ & $\begin{array}{l}\text { Bankruptcy and } \\
\text { reorganization laws; } \\
\text { LLSV (1998) }\end{array}$ \\
\hline $\begin{array}{l}\text { Creditor rights } \\
\text { Index }\end{array}$ & $\begin{array}{l}\text { An index aggregating different creditor rights. The index is formed by } \\
\text { adding "1" when: (1) the country imposes restrictions, such as } \\
\text { creditors' consent or minimum dividends to file for reorganization; (2) } \\
\text { secured creditors are able to gain possession of their security once the } \\
\text { reorganization petition has been approved (no automatic stay); (3) } \\
\text { secured creditors are ranked first in the distribution of the proceeds } \\
\text { that result from the disposition of the assets of a bankrupt firm; and } \\
\text { (4) the debtor does not retain the administration of its property } \\
\text { pending the resolution of the reorganization. The index ranges from } \\
\text { zero to four. }\end{array}$ & $\begin{array}{l}\text { Bankruptcy and } \\
\text { reorganization laws; } \\
\text { LLSV (1998) }\end{array}$ \\
\hline
\end{tabular}

Secondary source: $\operatorname{LLSV}(1997,1998)$ 


\section{A.2. Institutional Variables}

\begin{tabular}{|l|l|l|}
\hline Variables & Definition & Original Source \\
\hline $\begin{array}{l}\text { Legal } \\
\text { Formalism }\end{array}$ & $\begin{array}{l}\text { The Index measures substantive and procedural statutory } \\
\text { intervention in judicial cases at lower-level civil trial courts, } \\
\text { and is formed by adding up these indices: 1) professionals } \\
\text { vs. laymen; 2) written vs. oral elements; 3) legal } \\
\text { justification; 4) statutory regulation of evidence; 5) control } \\
\text { of superior review; 6) engagement formalities; 7) } \\
\text { independent procedural actions. }\end{array}$ & $\begin{array}{l}\text { Survey of Lex Mundi/Lex } \\
\text { Africa association of law } \\
\text { firms; DLLS (2003), and } \\
\text { details available at } \\
\text { http://iicg.som.yale.edu/ }\end{array}$ \\
\hline $\begin{array}{l}\text { Property Rights } \\
\text { Index }\end{array}$ & $\begin{array}{l}\text { Variables includes freedom from government influence } \\
\text { over the judicial system, commercial code defining } \\
\text { contracts, sanctioning of foreign arbitration of contract } \\
\text { disputes, government expropriation of property, corruption } \\
\text { within the judiciary, delays in receiving judicial decisions, } \\
\text { and legally granted and protected private property. }\end{array}$ & $\begin{array}{l}\text { 2000 Index of Economic } \\
\text { Freedom (Heritage }\end{array}$ \\
\hline Corruption & $\begin{array}{l}\text { ICR's assessment of the corruption in government. Lower } \\
\text { scores indicate that "high government officials are likely to } \\
\text { demand special payments" and "illegal payments are } \\
\text { generally expected throughout lower levels of government" } \\
\text { in the form of "bribes connected with import and export } \\
\text { licenses, tax assessment, policy protection, etc." Average of } \\
\text { the months of April and October of the monthly index } \\
\text { between 1982 and 1995. Scale from 0 to 10, with lower } \\
\text { scores for higher levels of corruption (we changed the scale } \\
\text { from its original" range going from zero to six) }\end{array}$ & $\begin{array}{l}\text { International Country Risk } \\
\text { Guide; LLSV (1998) }\end{array}$ \\
\hline
\end{tabular}

\section{A.3. Miscellaneous Country-level Variables}

\begin{tabular}{|l|l|l|}
\hline Variable & Description & Sources \\
\hline $\begin{array}{l}\text { Economic } \\
\text { Development }\end{array}$ & $\begin{array}{l}\text { Average of Log (per capita GDP) over the period 1994-2002; } \\
\text { measures a country's overall economic status (developed vs. } \\
\text { developing countries) }\end{array}$ & World Bank \\
\hline $\begin{array}{l}\text { Financial } \\
\text { Development }\end{array}$ & $\begin{array}{l}\text { Claims on private sector by banks as share of } \\
\text { GDP, averaged over the 1994 to 1997 period }\end{array}$ & $\begin{array}{l}\text { Demirguc-Kunt and Levine } \\
(2000)\end{array}$ \\
\hline $\begin{array}{l}\text { Percentage } \\
\text { change in GDP }\end{array}$ & $\begin{array}{l}\text { Percent change in GDP in two adjacent years, measuring } \\
\text { business cycle of a country }\end{array}$ & World Bank \\
\hline
\end{tabular}




\section{References:}

1. Acemoglu, Daron, and Simon Johnson, 2003. "Unbundling Institutions: Law vs. Politics," working paper, MIT.

2. and James Robinson, 2001. "The Colonial Origins of Comparative Development: An Empirical Investigation,” American Economic Review, 91 (5), 1369-1401.

3. and 2002. "Reversal of Fortune: Geography and Institutions in the Making of the Modern World Income Distribution,” Quarterly Journal of Economics, 117, 1231-1294.

4. Aggarwal, Reena, Leora Klapper, and Peter Wysocki, 2003. "Portfolio Preferences of Foreign Institutional Investors," working paper, Georgetown University.

5. Allen, Franklin, Jun Qian, and Meijun Qian, 2004. "Law, finance, and economic growth in China," forthcoming, Journal of Financial Economics.

6. Bae, Kee-Hong and Vidhan K. Ghoyal, 2003, "Property Rights Protection and Bank Loan Pricing," mimeo, Hong Kong University of Science and Technology.

7. Beck, Thorsten, Asli Demirgüç-Kunt, and Ross Levine, 2003a. "Law, Endowments, and Finance," Journal of Financial Economics 70, 137-181.

8. ___ _ _ _ and ___ 2003b. "Law and Finance: Why Does Legal Origin Matter?” Journal of Comparative Economics 31, 653-675.

9. ___ ___ and ___, 2003c. "Law and Firms' Access to Finance," working paper, working paper, University of Minnesota.

10. Bergman, Nittai, and Daniel Nicolaievsky, 2003, "Investor Protection and the Coasian View," working paper, Harvard University.

11. Bolton, Patrick and David Scharfstein, 1996, "Optimal Debt Contracts and the Number of Creditors," Journal of Political Economy 104, 1-25.

12. Coase, Ronald, 1937. "The nature of firm," Economica, Vol. 4, 386-405.

13. ___ 1960. "The problem of social cost," Journal of Law and Economics, Vol. 3, 1-44.

14. Demirgüç-Kunt, Asli, and Ross Levine, 2002. Financial Structure and Economic Growth: Crosscountry Comparisons of Banks, Markets, and Development, MIT Press, Cambridge, Massachusetts.

15. ___ and Vojislav Maksimovic, 1998. "Law, Finance, and Firm Growth,” Journal of Finance 53, 2107-37.

16. Diamond, Douglas, 2004, "Committing to Commit: Short-term Debt When Enforcement is Costly," AFA Presidential Address.

17. Djankov, Simeon, Rafael La Porta, Florencio Lopez-de-Silanes, and Andre Shleifer, 2002. "Regulation of Entry," Quarterly Journal of Economics 117, 1-37.

18. , and , 2003. "Courts," Quarterly Journal of Economics 118 (2), 453-517. 
19. Esty, Benjamin, 2004, "When do Foreign Banks Finance Domestic Projects? New Evidence on the Importance of Legal and Financial Systems," mimeo, Harvard Business School.

20. ___ and Megginson, William L., 2003, "Creditor Rights, Enforcement, and Debt Ownership Structure: Evidence from the Global Syndicated Loan Market," Journal of Financial and Quantitative Analysis 38, 37-59.

21. Giannetti, Mariassunta, 2003. "Do Better Institutions Mitigate Agency Problems? Evidence from Corporate Finance Choices," Journal of Financial and Quantitative Analysis 38, 185-212.

22. Hayek, Friedrich, 1960. The Constitution of Liberty, University of Chicago Press, Chicago, IL.

23. Jappelli, Tullio, and Marco Pagano, 2002. "Information Sharing, Lending and Defaults: Cross-country Evidence," Journal of Banking and Finance 26.

24. , and Magda Bianco, 2002. "Courts and Banks: Effects of Judicial Enforcement on Credit Markets," forthcoming, Journal of Money, Credit and Banking.

25. Jayaratne, Jith and Philip E. Strahan, 1996. "The Finance-Growth Nexus: Evidence from Bank Branch Deregulation," Quarterly Journal of Economics 111(3), 639-70.

26. Johnson, Simon, John McMillan, and Christopher Woodruff, 2002. "Property rights and finance," American Economic Review 92, 1335-1356.

27. Kaplan, Steven, Frederic Martel, and Per Stromberg, 2003, "How do Legal Differences and Learning affect Financial Contracts?” NBER Working Paper no. 10097.

28. King, Robert, and Ross Levine, 1993. "Finance and Growth: Schumpeter Might Be Right," Quarterly Journal of Economics 108 (3), 717-738.

29. La Porta, Rafael, Florencio Lopez-de-Silanes, and Andrei Shleifer, 1999. “Corporate Ownership Around the World," Journal of Finance 54 (2), 471-517.

30. _______ and ___, 2002. "Government Ownership of Banks," Journal of Finance 57 (1), 265-302.

31. ___ _____ a a _ a Robert Vishny, 1997. "Legal determinants of external finance," Journal of

Finance 52, 1131-1150.

32. ___ ______ and __ , 1998, "Law and Finance," Journal of Political Economy 106, 1113-1155.

33. ___ ______ and __ _ 1999, "The Quality of Government," Journal of Law, Economics, and Organization 15, 222-279.

34. , and __ 2000a, "Investor Protection and Corporate Governance," Journal of Financial Economics 58 (1-2).

35. ___ ____ , and __ 2000b, “Agency Problems and Dividend Policy Around the World," Journal of Finance 55 (1), 1-34.

36. , and _ _ 2002. "Investor Protection and Corporate Valuation," Journal of Finance $57,1147-1170$. 
37. and Guillermo Zamarripa, 2003. "Related Lending,” Quarterly Journal of Economics 118 (1), 231-268.

38. Lerner, Josh, and Antoinette Schoar, 2004, "Does Legal Enforcement Affect Financial Transactions? The Contractual Channel in Private Equity," forthcoming, Quarterly Journal of Economics.

39. Levine, Ross, 1999. "Law, finance, and economic growth," Journal of Financial Intermediation 8, 3667.

40. , and Sara Zervos, 1998. "Stock Markets, Banks, and Economic Growth," American Economic Review 88, 537-558.

41. McKinnon, R., 1973. Money and Capital in Economic Development. Brookings Institution Press.

42. Mian, Atif, 2004, "Distance Constraints: The Limits of Foreign Lending in Poor Economies," mimeo, University of Chicago.

43. Norton, Joseph J., 1997, "International Syndicated Lending and Economic Development in Latin America: The Legal Context," London Institute of International Banking \& Development Law.

44. Ongena, Steven, and David Smith, 2000. "What Determines the Number of Bank Relationships? Crosscountry Evidence," Journal of Financial Intermediation 9 (1), 26-56.

45. Petersen, Mitch, and Raghuram Rajan, 1994. "The benefits of firm-creditor relationships: Evidence from small-business data," Journal of Finance 49, 3-37.

46. Posner, Richard A., 1973. Economic Analysis of the Law, Little-Brown, Boston, MA.

47. Rajan, Raghuram, and Luigi Zingales, 1998. "Financial Dependence and Growth," American Economic Review 88, 559-87.

48. Rossi, Stefano, and Paolo Volpin, 2004. "Cross-country Determinants of Mergers and Acquisitions," Journal of Financial Economics 74, 277-304.

49. Sapienza, Paola, 2004. "The Effects of Government Ownership on Bank Lending," Journal of Financial Economics, 72, 357-384.

50. Siegel, Jordan, 2004. "Can Foreign Firms Bond Themselves Effectively by Renting U.S. Securities Laws?" forthcoming, Journal of Financial Economics.

51. Strahan, Phillip, 1999. "Borrower Risk and the Price and Nonprice Terms of Bank Loans," working paper, Banking studies function, New York Fed.

52. Stulz, Rene, and Rohan Williamson, 2003. "Culture, openness, and finance," forthcoming, Journal of Financial Economics 70, 261-300.

53. Sufi, Amir, 2004, "Agency and Renegotiation in Corporate Finance: Evidence from Syndicated Loans," mimeo, MIT. 


\section{Table 1}

\section{Summary Statistics for Loan-Level Variables}

Summary statistics on the loan terms by the legal origin of the borrower country are presented here. The source of data is LPC's Dealscan database. The sample of loans including those originated in 1994 through the middle of 2003. Loans from to firms in financial or regulated industries, as well a public sector loans, are dropped.

\begin{tabular}{|c|c|c|c|}
\hline Groups of Countries (by legal origins) & Mean & $\begin{array}{c}\text { Standard } \\
\text { Deviation }\end{array}$ & $\begin{array}{c}\text { Number of } \\
\text { Loans }\end{array}$ \\
\hline English Legal Origin & $(1)$ & $(2)$ & $(3)$ \\
\hline Number of Lenders & 5.1 & 6.6 & 8,957 \\
\hline Percent held by Government Banks & 5.2 & 16.2 & 8,957 \\
\hline Percent held by Domestic Banks & 29.3 & 36.9 & 8,957 \\
\hline One if Secured & 0.33 & - & 4,123 \\
\hline Maturity (Months) & 61 & 41 & 7,652 \\
\hline Drawn All-in Spread (BPS over LIBOR) & 164 & 113 & 2,018 \\
\hline Loan Size $(\mathrm{MM} \$ \mathrm{~s})$ & 176 & 444 & 8,957 \\
\hline \multicolumn{4}{|l|}{ French Legal Origin } \\
\hline Number of Lenders & 7.4 & 8.4 & 5,427 \\
\hline Percent held by Government Banks & 5.9 & 17.2 & 5,427 \\
\hline Percent held by Domestic Banks & 30.6 & 36.4 & 5,427 \\
\hline One if Secured & 0.59 & - & 1,538 \\
\hline Maturity (Months) & 66 & 42 & 4,542 \\
\hline Drawn All-in Spread (BPS over LIBOR) & 180 & 120 & 2,655 \\
\hline Loan Size (MM\$s) & 160 & 376 & 5,427 \\
\hline \multicolumn{4}{|l|}{ German Legal Origin } \\
\hline Number of Lenders & 6.0 & 6.9 & 5,526 \\
\hline Percent held by Government Banks & 6.7 & 15.7 & 5,526 \\
\hline Percent held by Domestic Banks & 70.7 & 38.9 & 5,526 \\
\hline One if Secured & 0.27 & - & 2,062 \\
\hline Maturity (Months) & 50 & 35 & 5,242 \\
\hline Drawn All-in Spread (BPS over LIBOR) & 170 & 114 & 657 \\
\hline Loan Size $(\mathrm{MM} \$ \mathrm{~s})$ & 159 & 468 & 5,526 \\
\hline \multicolumn{4}{|l|}{ Scandinavian Legal Origin } \\
\hline Number of Lenders & 6.9 & 7.3 & 372 \\
\hline Percent held by Government Banks & 12.5 & 19.8 & 372 \\
\hline Percent held by Domestic Banks & 20.2 & 29.0 & 372 \\
\hline One if Secured & 0.75 & - & 36 \\
\hline Maturity (Months) & 72 & 48 & 274 \\
\hline Drawn All-in Spread (BPS over LIBOR) & 164 & 135 & 215 \\
\hline Loan Size $(\mathrm{MM} \$ \mathrm{~s})$ & 224 & 456 & 372 \\
\hline \multicolumn{4}{|l|}{ Socialist Legal Origin } \\
\hline Number of Lenders & 5.3 & 5.3 & 1,086 \\
\hline Percent held by Government Banks & 21.5 & 32.4 & 1,086 \\
\hline Percent held by Domestic Banks & 9.6 & 23.1 & 1,086 \\
\hline One if Secured & 0.49 & - & 472 \\
\hline Maturity (Months) & 62 & 43 & 873 \\
\hline Drawn All-in Spread (BPS over LIBOR) & 230 & 147 & 268 \\
\hline Loan Size $(\mathrm{MM} \$ \mathrm{~s})$ & 133 & 491 & 1,086 \\
\hline
\end{tabular}




\section{Table 2 \\ Summary Statistics for Country-Level Variables}

Summary statistics for (borrower) country-level variables across five legal-origin groupings are presented here. The mean for each variable is obtained by taking the simple average of the scores/index of the group countries. Detailed descriptions and sources for the variables are presented in Appendix A.1.

\begin{tabular}{|c|c|c|c|}
\hline Groups of Countries (by legal origins) & Mean & $\begin{array}{c}\text { Standard } \\
\text { Deviation }\end{array}$ & $\begin{array}{c}\text { Number of } \\
\text { Countries }\end{array}$ \\
\hline English Legal Origin & $(1)$ & (2) & (3) \\
\hline Property Rights ( 1 to 5,5 means best protection of property) & 3.92 & 0.94 & 36 \\
\hline Check-Based Index of Legal Formalism (1 to 7, 7 means most formal) & 2.75 & 0.85 & 34 \\
\hline Creditor Rights ( 0 to 4, 4 means greatest level of creditor protection) & 2.46 & 1.04 & 28 \\
\hline Corruption ( 1 to 10,10 means least corrupt) & 5.70 & 2.53 & 33 \\
\hline \multicolumn{4}{|l|}{ French Legal Origin } \\
\hline Property Rights ( 1 to 5, 5 means best protection of property) & 3.24 & 0.95 & 49 \\
\hline Check-Based Index of Legal Formalism (1 to 7, 7 means most formal) & 4.29 & 1.01 & 40 \\
\hline Creditor Rights ( 0 to 4,4 means greatest level of creditor protection) & 1.43 & 1.05 & 46 \\
\hline Corruption ( 1 to 10,10 means least corrupt) & 5.24 & 1.84 & 51 \\
\hline \multicolumn{4}{|l|}{ German Legal Origin } \\
\hline Property Rights ( 1 to 5, 5 means best protection of property) & 5.00 & 0.00 & 5 \\
\hline Check-Based Index of Legal Formalism (1 to 7, 7 means most formal) & 3.15 & 0.44 & 6 \\
\hline Creditor Rights ( 0 to 4, 4 means greatest level of creditor protection) & 2.00 & 1.00 & 5 \\
\hline Corruption ( 1 to 10,10 means least corrupt) & 8.03 & 1.68 & 6 \\
\hline \multicolumn{4}{|l|}{ Scandinavian Legal Origin } \\
\hline Property Rights ( 1 to 5, 5 means best protection of property) & 4.80 & 0.45 & 5 \\
\hline Check-Based Index of Legal Formalism (1 to 7, 7 means most formal) & 3.15 & 0.59 & 5 \\
\hline Creditor Rights ( 0 to 4, 4 means greatest level of creditor protection) & 1.75 & 0.96 & 4 \\
\hline Corruption ( 1 to 10,10 means least corrupt) & 10.00 & 0.00 & 5 \\
\hline \multicolumn{4}{|l|}{ Socialist Legal Origin } \\
\hline Property Rights ( 1 to 5,5 means best protection of property) & 2.76 & 0.94 & 21 \\
\hline Check-Based Index of Legal Formalism (1 to 7, 7 means most formal) & 3.98 & 0.49 & 15 \\
\hline Creditor Rights ( 0 to 4, 4 means greatest level of creditor protection) & 2.13 & 0.97 & 23 \\
\hline Corruption (1 to 10,10 mean least corrupt) & 6.23 & 1.13 & 9 \\
\hline
\end{tabular}


Table 3

Correlation Matrix of Firm Characteristics and Legal and Institutional Variables

This table reports the Pearson correlation coefficient between three firm characteristics from Worldscope with four legal and institutional variables which are the focus of our regressions. The sample of firms all appear on both Dealscan and Worldscope, and was selected in a stratified random sample (by country, with a maximum of 20 firms per country) subject to this data constraint. The table contains the correlation, the p-value in parentheses, and the number of observations in square brackets.

Property Rights

Check-Based Index of Legal Formalism

Creditor Rights

Corruption
Firm Size Log of Market Capitalization

0.09

(0.06) [386]

$-0.06$

$(0.25)$

[402]

$-0.01$

(0.84)

[402]

0.33

(0.00)

[401]
Firm Characteristic:

\begin{tabular}{cc}
$\begin{array}{c}\text { Profitability - } \\
\text { Net Income / Assets }\end{array}$ & $\begin{array}{c}\text { Total Debt / } \\
\text { Assets }\end{array}$ \\
\hline-0.03 & -0.03 \\
$(0.56)$ & $(0.56)$ \\
{$[404]$} & {$[405]$} \\
& \\
0.06 & 0.06 \\
$(0.25)$ & $(0.25)$ \\
{$[420]$} & {$[421]$} \\
& \\
-0.06 & -0.07 \\
$(0.18)$ & $(0.18)$ \\
{$[420]$} & {$[421]$} \\
-0.01 & -0.01 \\
$(0.88)$ & $(0.88)$ \\
{$[419]$} & {$[420]$}
\end{tabular}


Table 4

Regressions Relating Loan Ownership to Country Characteristics

Regressions contain year, ratings, 1-digit SIC industry, and loan purpose indicators. Loan observations are clustered by borrower country. We also include an indicator for loans denominated in a major currency, and an indicator for multinational companies. The source of data is LPC's Dealscan database. The sample of loans includes those originated in 1994 through the middle of 2003. Loans to firms in financial or regulated industries, as well a public sector loans, are dropped (SIC 4, 6, and 9). Regressions without firm controls exclude ratings, industry, multinational indicators and log of loan commitment amount.

\begin{tabular}{|c|c|c|c|c|c|c|}
\hline \multirow[t]{2}{*}{ Explanatory Variable } & \multicolumn{2}{|c|}{$\begin{array}{l}\text { Log of } \\
\text { Number of Lenders }\end{array}$} & \multicolumn{2}{|c|}{$\begin{array}{l}\text { Share Held by } \\
\text { Government Banks }\end{array}$} & \multicolumn{2}{|c|}{$\begin{array}{l}\text { Share held by } \\
\text { Domestic Banks }\end{array}$} \\
\hline & $(1)$ & (2) & $(3)$ & (4) & $(5)$ & (6) \\
\hline \multirow[t]{2}{*}{ One if loan is a line of credit } & 0.219 & 0.273 & -0.949 & -0.942 & 3.353 & 2.282 \\
\hline & $(3.76)^{* *}$ & $(6.08)^{* *}$ & $(1.87)^{*}$ & $(1.73)^{*}$ & $(2.76)^{* *}$ & $(1.46)$ \\
\hline \multirow[t]{2}{*}{ Log of loan commitment amount } & 0.170 & - & -0.329 & - & -3.685 & - \\
\hline & $(5.28)^{* *}$ & - & $(1.33)$ & - & $(6.06)^{* *}$ & - \\
\hline \multirow[t]{2}{*}{ One if French legal origin } & 0.220 & 0.258 & 1.234 & 1.465 & -12.936 & -13.979 \\
\hline & $(2.03)^{*}$ & $(2.48)^{*}$ & $(0.64)$ & $(0.74)$ & $(1.70)^{*}$ & $(1.66)^{*}$ \\
\hline \multirow[t]{2}{*}{ One if German legal origin } & 0.252 & 0.279 & 2.894 & 3.204 & 13.513 & 11.493 \\
\hline & $(1.96)^{*}$ & $(1.92)^{*}$ & $(1.06)$ & $(1.13)$ & $(2.16)^{*}$ & $(1.74)^{*}$ \\
\hline \multirow[t]{2}{*}{ One if Scandinavian legal origin } & -0.166 & -0.035 & 12.043 & 12.248 & -10.906 & -18.792 \\
\hline & $(1.09)$ & $(0.21)$ & $(4.67)^{* *}$ & $(4.64)^{* *}$ & $(1.11)$ & $(1.81)^{*}$ \\
\hline \multirow[t]{2}{*}{ One if Socialist legal origin } & 0.054 & -0.027 & 13.869 & 14.056 & -26.847 & -26.816 \\
\hline & $(0.31)$ & $(0.15)$ & $(3.22)^{* *}$ & $(3.16)^{* *}$ & $(3.46)^{* *}$ & $(3.26)^{* *}$ \\
\hline \multirow[t]{2}{*}{ Economic Development } & -0.150 & -0.146 & -2.951 & -2.942 & 3.179 & 2.277 \\
\hline & $(2.49)^{*}$ & $(2.16)^{*}$ & $(2.55)^{*}$ & $(2.37)^{*}$ & $(0.67)$ & $(0.44)$ \\
\hline \multirow[t]{2}{*}{ Financial Development } & 0.001 & -0.067 & -1.084 & -0.952 & 17.703 & 20.108 \\
\hline & $(0.01)$ & $(0.80)$ & $(0.47)$ & $(0.39)$ & $(3.10)^{* *}$ & $(3.27)^{* *}$ \\
\hline \multirow[t]{2}{*}{ Percentage change in GDP } & 0.002 & 0.003 & -0.016 & -0.016 & -0.098 & -0.142 \\
\hline & $(0.75)$ & $(1.49)$ & $(0.31)$ & $(0.31)$ & $(0.82)$ & $(1.03)$ \\
\hline \multirow[t]{2}{*}{ Creditors' rights } & -0.064 & -0.067 & 0.342 & 0.425 & -2.614 & -2.350 \\
\hline & $(1.62)$ & $(1.58)$ & $(0.45)$ & $(0.52)$ & $(0.97)$ & $(0.77)$ \\
\hline \multirow[t]{2}{*}{ Legal formalism } & 0.030 & 0.021 & -0.034 & -0.033 & 9.272 & 10.045 \\
\hline & $(0.52)$ & $(0.31)$ & $(0.04)$ & $(0.04)$ & $(2.97)^{* *}$ & $(3.07)^{* *}$ \\
\hline \multirow[t]{2}{*}{ Property rights } & 0.081 & 0.099 & 3.266 & 3.135 & -8.640 & -8.940 \\
\hline & $(0.94)$ & $(1.07)$ & $(1.90)^{*}$ & $(1.73)^{*}$ & $(1.88)^{*}$ & $(1.74)^{*}$ \\
\hline \multirow[t]{2}{*}{ Corruption (higher means less corrupt) } & 0.066 & 0.087 & -0.414 & -0.449 & 1.491 & 1.585 \\
\hline & $(1.77)^{*}$ & $(2.28)^{*}$ & $(0.65)$ & $(0.68)$ & $(0.55)$ & $(0.55)$ \\
\hline Observations & 11,083 & 11,083 & 11,083 & 11,083 & 11,083 & 11,083 \\
\hline Number of Countries & 57 & 57 & 57 & 57 & 57 & 57 \\
\hline Firm Controls Included? & Yes & No & Yes & No & Yes & No \\
\hline R-squared & 0.21 & 0.15 & 0.09 & 0.09 & 0.29 & 0.26 \\
\hline Estimation Technique & OLS & OLS & OLS & OLS & OLS & OLS \\
\hline
\end{tabular}

* Significant at $10 \% ; * *$ significant at $1 \%$ 
Table 5

Regressions Relating Loan Contract Terms to Country Characteristics

Regressions contain year, ratings, 1-digit SIC industry, and loan purpose indicators. Loan observations are clustered by borrower country. We also include an indicator for loans denominated in a major currency, and an indicator for multinational companies. The source of data is LPC's Dealscan database. The sample of loans includes those originated in 1994 through the middle of 2003. Loans to firms in financial or regulated industries, as well a public sector loans, are dropped (SIC 4, 6, and 9). Regressions without firm controls exclude ratings, industry, multinational indicators and log of loan commitment amount.

\section{Panel A: Single Creditor Rights Index (ranging from 0 to 4)}

\begin{tabular}{|c|c|c|c|c|c|c|}
\hline \multirow[t]{2}{*}{ Explanatory Variable } & \multicolumn{2}{|c|}{ Secured Indicator } & \multicolumn{2}{|c|}{$\begin{array}{l}\text { Log of Maturity in } \\
\text { Months }\end{array}$} & \multicolumn{2}{|c|}{$\begin{array}{l}\text { Log of Drawn All-in } \\
\text { Spread }\end{array}$} \\
\hline & (1) & $(2)$ & (3) & (4) & $(5)$ & (6) \\
\hline \multirow[t]{2}{*}{ One if loan is a line of credit } & -0.013 & -0.023 & -0.544 & -0.549 & -0.302 & -0.378 \\
\hline & $(0.42)$ & $(0.66)$ & $(4.09)^{* *}$ & $(4.07)^{* *}$ & $(6.00)^{* *}$ & $(5.87)^{* *}$ \\
\hline \multirow[t]{2}{*}{ Log of loan commitment amount } & -0.037 & - & 0.005 & - & -0.154 & - \\
\hline & $(2.87)^{* *}$ & - & $(0.25)$ & - & $(8.15)^{* *}$ & - \\
\hline \multirow[t]{2}{*}{ One if French legal origin } & 0.102 & 0.096 & -0.012 & -0.025 & -0.080 & -0.080 \\
\hline & $(1.21)$ & $(1.06)$ & $(0.14)$ & $(0.28)$ & $(0.56)$ & $(0.51)$ \\
\hline \multirow[t]{2}{*}{ One if German legal origin } & -0.308 & -0.314 & -0.198 & -0.203 & 0.012 & -0.057 \\
\hline & $(3.59)^{* *}$ & $(3.29)^{* *}$ & $(1.69)^{*}$ & $(1.77)^{*}$ & $(0.10)$ & $(0.45)$ \\
\hline \multirow[t]{2}{*}{ One if Scandinavian legal origin } & 0.347 & 0.375 & -0.176 & -0.200 & -0.108 & -0.200 \\
\hline & $(2.24)^{*}$ & $(2.63)^{* *}$ & $(1.71)^{*}$ & $(1.80)^{*}$ & $(0.64)$ & $(1.14)$ \\
\hline \multirow[t]{2}{*}{ One if Socialist legal origin } & -0.230 & -0.221 & -0.196 & -0.205 & -0.376 & -0.355 \\
\hline & $(3.85)^{* *}$ & $(3.58)^{* *}$ & $(1.52)$ & $(1.59)$ & $(1.42)$ & $(1.18)$ \\
\hline \multirow[t]{2}{*}{ Economic Development } & 0.085 & 0.090 & -0.061 & -0.059 & -0.221 & -0.203 \\
\hline & $(1.77)^{*}$ & $(1.89)^{*}$ & $(1.33)$ & $(1.28)$ & $(1.48)$ & $(1.13)$ \\
\hline \multirow[t]{2}{*}{ Financial Development } & 0.172 & 0.168 & -0.120 & -0.125 & 0.027 & -0.007 \\
\hline & $(1.90)^{*}$ & $(1.76)^{*}$ & $(1.45)$ & $(1.62)$ & $(0.17)$ & $(0.05)$ \\
\hline \multirow[t]{2}{*}{ Percentage change in GDP } & 0.000 & 0.001 & 0.002 & 0.002 & 0.004 & 0.004 \\
\hline & $(0.25)$ & $(0.52)$ & $(1.29)$ & $(1.28)$ & $(0.97)$ & $(1.05)$ \\
\hline \multirow[t]{2}{*}{ Creditors' rights } & 0.081 & 0.077 & 0.095 & 0.092 & -0.018 & 0.007 \\
\hline & $(2.67)^{* *}$ & $(2.40)^{*}$ & $(3.04)^{* *}$ & $(3.04)^{* *}$ & $(0.38)$ & $(0.14)$ \\
\hline \multirow[t]{2}{*}{ Legal formalism } & 0.076 & 0.077 & 0.133 & 0.136 & -0.027 & -0.016 \\
\hline & $(2.61)^{* *}$ & $(2.48)^{*}$ & $(4.50)^{* *}$ & $(4.64)^{* *}$ & $(0.26)$ & $(0.15)$ \\
\hline \multirow[t]{2}{*}{ Property rights } & -0.213 & -0.210 & 0.032 & 0.034 & 0.005 & -0.044 \\
\hline & $(4.69)^{* *}$ & $(4.70)^{* *}$ & $(0.68)$ & $(0.72)$ & $(0.04)$ & $(0.31)$ \\
\hline \multirow[t]{2}{*}{ Corruption (higher means less corrupt) } & -0.023 & -0.026 & 0.093 & 0.095 & -0.045 & -0.044 \\
\hline & $(0.76)$ & $(0.83)$ & $(3.16)^{* *}$ & $(3.42)^{* *}$ & $(0.48)$ & $(0.41)$ \\
\hline Observations & 4,474 & 4,474 & 9,578 & 9,578 & 3,608 & 3,608 \\
\hline Number of Countries & 46 & 46 & 57 & 57 & 42 & 42 \\
\hline Firm Controls Included? & Yes & No & Yes & No & Yes & No \\
\hline R-squared (pseudo for probits) & 0.23 & 0.2 & 0.33 & 0.32 & 0.52 & 0.43 \\
\hline Estimation Technique & Probit & Probit & OLS & OLS & OLS & OLS \\
\hline
\end{tabular}

* Significant at $10 \%$; * significant at $1 \%$ 
Table 5 (continued)

Regressions Relating Loan Contract Terms to Country Characteristics

Panel B: Two Creditor Rights Indices (each ranging from 0 to 2)

\begin{tabular}{|c|c|c|c|c|c|c|}
\hline \multirow[t]{2}{*}{ Explanatory Variable } & \multicolumn{2}{|c|}{ Secured Indicator } & \multicolumn{2}{|c|}{$\begin{array}{l}\text { Log of Maturity in } \\
\text { Months }\end{array}$} & \multicolumn{2}{|c|}{$\begin{array}{l}\text { Log of Drawn All-in } \\
\text { Spread }\end{array}$} \\
\hline & (1) & (2) & (3) & (4) & $(5)$ & (6) \\
\hline \multirow[t]{2}{*}{ One if loan is a line of credit } & -0.004 & -0.015 & -0.526 & -0.532 & -0.291 & -0.367 \\
\hline & $(0.14)$ & $(0.46)$ & $(3.88)^{* *}$ & $(3.84)^{* *}$ & $(5.36)^{* *}$ & $(5.32)^{* *}$ \\
\hline \multirow[t]{2}{*}{ Log of loan commitment amount } & -0.038 & - & 0.001 & - & -0.153 & - \\
\hline & $(2.86)^{* *}$ & - & $(0.05)$ & - & $(7.93)^{* *}$ & - \\
\hline \multirow[t]{2}{*}{ One if French legal origin } & 0.289 & 0.273 & 0.003 & -0.018 & -0.352 & -0.357 \\
\hline & $(2.88)^{* *}$ & $(2.62)^{* *}$ & $(0.04)$ & $(0.20)$ & $(2.61)^{*}$ & $(2.48)^{*}$ \\
\hline \multirow[t]{2}{*}{ One if German legal origin } & -0.232 & -0.239 & -0.206 & -0.216 & -0.091 & -0.156 \\
\hline & $(2.78)^{* *}$ & $(2.64)^{* *}$ & $(1.89)^{*}$ & $(2.02)^{*}$ & $(0.90)$ & $(1.48)$ \\
\hline \multirow[t]{2}{*}{ One if Scandinavian legal origin } & 0.338 & 0.355 & -0.246 & -0.285 & -0.295 & -0.393 \\
\hline & $(2.25)^{*}$ & $(2.62)^{* *}$ & $(2.44)^{*}$ & $(2.52)^{*}$ & $(1.78)^{*}$ & $(2.68)^{*}$ \\
\hline \multirow[t]{2}{*}{ Economic Development } & 0.038 & 0.046 & -0.088 & -0.086 & -0.402 & -0.421 \\
\hline & $(0.83)$ & $(1.00)$ & $(1.74)^{*}$ & $(1.70)^{*}$ & $(2.98)^{* *}$ & $(2.95)^{* *}$ \\
\hline \multirow[t]{2}{*}{ Financial Development } & 0.042 & 0.035 & -0.144 & -0.141 & -0.027 & -0.058 \\
\hline & $(0.53)$ & $(0.41)$ & $(1.71)^{*}$ & $(1.75)^{*}$ & $(0.15)$ & $(0.35)$ \\
\hline \multirow{2}{*}{ Percentage change in GDP } & 0.001 & 0.001 & 0.003 & 0.003 & 0.003 & 0.004 \\
\hline & $(0.28)$ & $(0.53)$ & $(1.61)$ & $(1.60)$ & $(0.84)$ & $(1.08)$ \\
\hline \multirow[t]{2}{*}{ Creditors' rights: ability to oust management } & 0.037 & 0.042 & -0.018 & -0.022 & -0.026 & 0.016 \\
\hline & $(0.97)$ & $(0.99)$ & $(0.42)$ & $(0.49)$ & $(0.28)$ & $(0.19)$ \\
\hline \multirow[t]{2}{*}{ Creditors' rights: ability to take collateral } & 0.126 & 0.123 & 0.128 & 0.125 & -0.191 & -0.188 \\
\hline & $(2.55)^{*}$ & $(2.27)^{*}$ & $(2.69) *$ & $(2.68)^{*}$ & $(2.09) *$ & $(2.02)^{*}$ \\
\hline \multirow[t]{2}{*}{ Legal formalism } & 0.034 & 0.040 & 0.092 & 0.097 & 0.076 & 0.109 \\
\hline & $(1.44)$ & $(1.72)$ & $(2.32)^{*}$ & $(2.38)^{*}$ & $(0.72)$ & $(1.10)$ \\
\hline \multirow[t]{2}{*}{ Property rights } & -0.080 & -0.078 & 0.086 & 0.081 & 0.161 & 0.133 \\
\hline & $(1.37)$ & $(1.27)$ & $(1.59)$ & $(1.49)$ & $(1.05)$ & $(0.80)$ \\
\hline \multirow[t]{2}{*}{ Corruption (higher means less corrupt) } & 0.008 & 0.004 & 0.106 & 0.106 & 0.008 & 0.023 \\
\hline & $(0.27)$ & $(0.14)$ & $(3.79)^{* *}$ & $(4.06)^{* *}$ & $(0.09)$ & $(0.29)$ \\
\hline Observations & 4,286 & 4,286 & 9,222 & 9,222 & 3,494 & 3,494 \\
\hline Number of Countries & 38 & 38 & 42 & 42 & 30 & 30 \\
\hline Firm Controls Included? & Yes & No & Yes & No & Yes & No \\
\hline R-squared (pseudo for probits) & 0.24 & 0.22 & 0.33 & 0.32 & 0.54 & 0.46 \\
\hline Estimation Technique & Probit & Probit & OLS & OLS & OLS & OLS \\
\hline
\end{tabular}

* Significant at $10 \% ; * *$ significant at $1 \%$ 
Table 6

Regressions Relating Loan Contract Terms to Country Characteristics With Loan Ownership Variables Included as Regressors

Regressions contain year, ratings, 1-digit SIC industry, and loan purpose indicators. Loan observations are clustered by borrower country. We also include an indicator for loans denominated in a major currency, and an indicator for multinational companies. The source of data is LPC's Dealscan database. The sample of loans includes those originated in 1994 through the middle of 2003.

Loans to firms in financial or regulated industries, as well a public sector loans, are dropped (SIC 4, 6, and 9). Regressions without firm controls exclude ratings, industry, multinational indicators and log of loan commitment amount.

\begin{tabular}{|c|c|c|c|c|c|c|}
\hline \multirow[t]{2}{*}{ Explanatory Variable } & \multicolumn{2}{|c|}{ Secured Indicator } & \multicolumn{2}{|c|}{$\begin{array}{l}\text { Log of Maturity in } \\
\text { Months }\end{array}$} & \multicolumn{2}{|c|}{$\begin{array}{l}\text { Log of Drawn All-in } \\
\text { Spread }\end{array}$} \\
\hline & (1) & (2) & (3) & (4) & (5) & (6) \\
\hline \multirow[t]{2}{*}{ One if loan is a line of credit } & -0.041 & -0.046 & -0.546 & -0.551 & -0.303 & -0.367 \\
\hline & $(1.71)$ & $(1.62)$ & $(4.08) * *$ & $(4.07)^{* *}$ & $(6.09) * *$ & $(6.12)^{* *}$ \\
\hline \multirow[t]{2}{*}{ Log of loan commitment amount } & -0.047 & - & 0.005 & - & -0.162 & - \\
\hline & $(3.13)^{* *}$ & - & $(0.24)$ & - & $(8.15)^{* *}$ & - \\
\hline \multirow[t]{2}{*}{ Log of Number of Lenders } & 0.066 & 0.053 & 0.012 & 0.012 & -0.016 & -0.101 \\
\hline & $(3.02)^{* *}$ & $(2.99)^{* *}$ & $(1.00)$ & $(1.03)$ & $(1.41)$ & $(6.69)^{* *}$ \\
\hline \multirow[t]{2}{*}{ Share held by Government Banks } & 0.000 & 0.000 & 0.002 & 0.002 & -0.003 & -0.002 \\
\hline & $(0.62)$ & $(0.48)$ & $(1.80)^{*}$ & $(1.69)^{*}$ & $(1.42)$ & $(0.93)$ \\
\hline \multirow[t]{2}{*}{ Share held by Domestic Banks } & 0.000 & 0.000 & 0.001 & 0.001 & -0.003 & -0.002 \\
\hline & $(0.17)$ & $(0.67)$ & $(1.58)$ & $(1.63)$ & $(4.53)^{* *}$ & $(2.66)^{*}$ \\
\hline \multirow{2}{*}{ One if French legal origin } & 0.091 & 0.090 & -0.010 & -0.022 & -0.066 & -0.066 \\
\hline & (1.08) & (1.00) & $(0.11)$ & $(0.25)$ & $(0.52)$ & $(0.46)$ \\
\hline \multirow[t]{2}{*}{ One if German legal origin } & -0.315 & -0.321 & -0.215 & -0.219 & 0.077 & 0.015 \\
\hline & $(3.70)^{* *}$ & $(3.38)^{* *}$ & $(1.93)^{*}$ & $(2.01)^{*}$ & $(0.75)$ & $(0.13)$ \\
\hline \multirow[t]{2}{*}{ One if Scandinavian legal origin } & 0.369 & 0.394 & -0.191 & -0.210 & -0.146 & -0.243 \\
\hline & $(2.30)^{*}$ & $(2.69)^{* *}$ & $(1.86)^{*}$ & $(1.90)^{*}$ & $(0.93)$ & $(1.37)$ \\
\hline \multirow[t]{2}{*}{ One if Socialist legal origin } & -0.236 & -0.221 & -0.204 & -0.210 & -0.421 & -0.396 \\
\hline & $(3.58)^{* *}$ & $(3.18)^{* *}$ & (1.59) & (1.62) & $(1.77)^{*}$ & (1.39) \\
\hline \multirow[t]{2}{*}{ Economic Development } & 0.091 & 0.093 & -0.055 & -0.053 & -0.168 & -0.180 \\
\hline & $(1.91)^{*}$ & $(1.85)^{*}$ & $(1.20)$ & (1.16) & (1.32) & (1.10) \\
\hline \multirow[t]{2}{*}{ Financial Development } & 0.179 & 0.172 & -0.127 & -0.134 & -0.038 & -0.061 \\
\hline & $(1.87)^{*}$ & $(1.70)^{*}$ & (1.60) & $(1.78)^{*}$ & $(0.27)$ & $(0.39)$ \\
\hline \multirow[t]{2}{*}{ Percentage change in GDP } & 0.000 & 0.001 & 0.002 & 0.002 & 0.003 & 0.004 \\
\hline & $(0.12)$ & $(0.41)$ & (1.33) & (1.33) & (0.94) & (1.14) \\
\hline \multirow[t]{2}{*}{ Creditors' rights } & 0.090 & 0.085 & 0.097 & 0.094 & -0.009 & 0.003 \\
\hline & $(3.02)^{* *}$ & $(2.70)^{* *}$ & $(3.13)^{* *}$ & $(3.12)^{* *}$ & $(0.21)$ & $(0.07)$ \\
\hline \multirow[t]{2}{*}{ Legal formalism } & 0.074 & 0.072 & 0.128 & 0.130 & -0.023 & -0.025 \\
\hline & $(2.46)^{*}$ & $(2.25)^{*}$ & $(4.28) * *$ & $(4.37)^{* *}$ & $(0.24)$ & $(0.24)$ \\
\hline \multirow[t]{2}{*}{ Property rights } & -0.223 & -0.215 & 0.028 & 0.031 & -0.026 & -0.053 \\
\hline & $(4.88)^{* *}$ & $(4.62)^{* *}$ & $(0.63)$ & $(0.67)$ & $(0.22)$ & $(0.39)$ \\
\hline \multirow[t]{2}{*}{ Corruption (higher means less corrupt) } & -0.025 & -0.028 & 0.092 & 0.093 & -0.031 & -0.030 \\
\hline & $(0.80)$ & $(0.91)$ & $(3.24)^{* *}$ & $(3.47)^{* *}$ & $(0.39)$ & $(0.31)$ \\
\hline Observations & 4,474 & 4,474 & 9,578 & 9,578 & 3,608 & 3,608 \\
\hline Number of Countries & 46 & 46 & 57 & 57 & 42 & 42 \\
\hline Firm Controls Included? & Yes & No & Yes & No & Yes & No \\
\hline R-squared (pseudo for probits) & 0.24 & 0.21 & 0.33 & 0.32 & 0.53 & 0.45 \\
\hline Estimation Technique & Probit & Probit & OLS & OLS & OLS & OLS \\
\hline
\end{tabular}

* Significant at $10 \% ; * *$ significant at $1 \%$ 
Table 7

Regressions Relating Loan Ownership to Country Characteristics

Rated vs. Unrated Borrowers

Regressions contain year, ratings, 1-digit SIC industry, and loan purpose indicators. Loan observations are clustered by borrower country. We also include an indicator for loans denominated in a major currency, and an indicator for multinational companies. The source of data is LPC's Dealscan database. The sample of loans includes those originated in 1994 through the middle of 2003. Loans to firms in financial or regulated industries, as well a public sector loans, are dropped (SIC 4, 6, and 9). Regressions without firm controls exclude ratings, industry, multinational indicators and log of loan commitment amount.

\begin{tabular}{|c|c|c|c|c|c|c|}
\hline \multirow[t]{2}{*}{ Explanatory Variable } & \multicolumn{2}{|c|}{$\begin{array}{l}\text { Log of } \\
\text { Number of Lenders }\end{array}$} & \multicolumn{2}{|c|}{$\begin{array}{l}\text { Share Held by } \\
\text { Government Banks }\end{array}$} & \multicolumn{2}{|c|}{$\begin{array}{l}\text { Share held by } \\
\text { Domestic Banks }\end{array}$} \\
\hline & (1) & (2) & (3) & (4) & (5) & (6) \\
\hline \multirow[t]{2}{*}{ One if loan is a line of credit } & 0.207 & 0.180 & -1.009 & -0.297 & 3.488 & -3.518 \\
\hline & $(3.34)^{* *}$ & $(4.41)^{* *}$ & $(2.02)^{*}$ & $(0.23)$ & $(2.49)^{*}$ & $(2.00)^{*}$ \\
\hline \multirow[t]{2}{*}{ Log of loan commitment amount } & 0.155 & 0.337 & -0.308 & -0.882 & -3.656 & -1.917 \\
\hline & $(5.10)^{* *}$ & $(14.48)^{* *}$ & $(1.19)$ & $(2.33)^{*}$ & $(5.61)^{* *}$ & $(2.57)^{*}$ \\
\hline \multirow[t]{2}{*}{ One if French legal origin } & 0.227 & 0.032 & 1.341 & -1.460 & -13.489 & 9.837 \\
\hline & $(2.15)^{*}$ & $(0.11)$ & $(0.68)$ & $(0.44)$ & $(1.74)^{*}$ & $(1.55)$ \\
\hline \multirow[t]{2}{*}{ One if German legal origin } & 0.212 & 0.377 & 2.538 & 4.197 & 14.384 & 16.729 \\
\hline & $(1.74)^{*}$ & $(1.93)^{*}$ & $(0.87)$ & $(1.74)^{*}$ & $(2.15)^{*}$ & $(4.59)^{* *}$ \\
\hline \multirow[t]{2}{*}{ One if Scandinavian legal origin } & -0.204 & -0.277 & 13.164 & 6.030 & -10.139 & -8.585 \\
\hline & $(1.31)$ & $(0.83)$ & $(4.99)^{* *}$ & $(1.08)$ & $(1.00)$ & $(1.09)$ \\
\hline \multirow[t]{2}{*}{ One if Socialist legal origin } & 0.063 & -1.003 & 14.079 & 10.720 & -28.084 & -2.550 \\
\hline & $(0.35)$ & $(1.91)$ & $(3.18)^{* *}$ & $(1.48)$ & $(3.65)^{* *}$ & $(0.22)$ \\
\hline \multirow[t]{2}{*}{ Economic Development } & -0.138 & -0.363 & -2.911 & -2.189 & 3.314 & 13.946 \\
\hline & $(2.30)^{*}$ & $(1.54)$ & $(2.42)^{*}$ & $(0.90)$ & $(0.69)$ & $(2.41)^{*}$ \\
\hline \multirow[t]{2}{*}{ Financial Development } & 0.022 & -0.297 & -0.869 & -2.140 & 18.213 & -12.540 \\
\hline & $(0.26)$ & $(1.64)$ & $(0.37)$ & $(0.80)$ & $(3.25)^{* *}$ & $(1.61)$ \\
\hline \multirow[t]{2}{*}{ Percentage change in GDP } & 0.001 & 0.017 & -0.022 & 0.129 & -0.067 & -0.275 \\
\hline & $(0.48)$ & $(2.65)^{*}$ & $(0.41)$ & $(1.37)$ & $(0.55)$ & $(1.35)$ \\
\hline \multirow[t]{2}{*}{ Creditors' rights } & -0.073 & 0.006 & 0.395 & -0.001 & -2.891 & 3.688 \\
\hline & $(1.82)^{*}$ & $(0.07)$ & $(0.50)$ & $(0.01)$ & $(1.10)$ & $(2.12)^{*}$ \\
\hline \multirow[t]{2}{*}{ Legal formalism } & 0.037 & 0.145 & -0.009 & 0.569 & 9.614 & -7.286 \\
\hline & $(0.61)$ & $(0.80)$ & $(0.01)$ & $(0.35)$ & $(3.26)^{* *}$ & $(2.75)^{* *}$ \\
\hline \multirow[t]{2}{*}{ Property rights } & 0.082 & -0.008 & 3.329 & 1.881 & -9.263 & -6.769 \\
\hline & $(0.91)$ & $(0.05)$ & $(1.88)^{*}$ & $(0.78)$ & $(1.98)^{*}$ & $(2.49)^{*}$ \\
\hline \multirow[t]{2}{*}{ Corruption (higher means less corrupt) } & 0.063 & 0.264 & -0.486 & 0.465 & 1.464 & -0.451 \\
\hline & $(1.75)^{*}$ & $(2.34)^{*}$ & $(0.71)$ & $(0.21)$ & $(0.54)$ & $(0.13)$ \\
\hline Observations & 10,324 & 759 & 10,324 & 759 & 10,324 & 759 \\
\hline Number of Countries & 57 & 32 & 57 & 32 & 57 & 32 \\
\hline Rated? & No & Yes & No & Yes & No & Yes \\
\hline R-squared & 0.16 & 0.43 & 0.09 & 0.16 & 0.3 & 0.29 \\
\hline Estimation Technique & OLS & OLS & OLS & OLS & OLS & OLS \\
\hline
\end{tabular}

* Significant at $10 \% ; * *$ significant at $1 \%$ 
Table 8

Regressions Relating Loan Contract Terms to Country Characteristics

Rated vs. Unrated Borrowers

Regressions contain year, ratings, 1-digit SIC industry, and loan purpose indicators. Loan observations are clustered by borrower country. We also include an indicator for loans denominated in a major currency, and an indicator for multinational companies. The source of data is LPC's Dealscan database. The sample of loans includes those originated in 1994 through the middle of 2003. Loans to firms in financial or regulated industries, as well a public sector loans, are dropped (SIC 4, 6, and 9). Regressions without firm controls exclude ratings, industry, multinational indicators and log of loan commitment amount.

\begin{tabular}{|c|c|c|c|c|c|c|}
\hline \multirow[t]{2}{*}{ Explanatory Variable } & \multicolumn{2}{|c|}{ Secured Indicator } & \multicolumn{2}{|c|}{$\begin{array}{l}\text { Log of Maturity in } \\
\text { Months }\end{array}$} & \multicolumn{2}{|c|}{$\begin{array}{l}\text { Log of Drawn All- } \\
\text { In Spread }\end{array}$} \\
\hline & (1) & (2) & (3) & (4) & (5) & (6) \\
\hline \multirow[t]{2}{*}{ One if loan is a line of credit } & -0.017 & - & -0.550 & -0.367 & -0.285 & -0.364 \\
\hline & $(0.51)$ & - & $(3.98)^{* *}$ & $(2.34)^{*}$ & $(6.01)^{* *}$ & $(3.58)^{* *}$ \\
\hline \multirow[t]{2}{*}{ Log of loan commitment amount } & -0.035 & - & 0.010 & -0.083 & -0.155 & -0.139 \\
\hline & $(2.77)^{* *}$ & - & $(0.51)$ & $(2.31)^{*}$ & $(7.23)^{* *}$ & $(7.06)^{* *}$ \\
\hline \multirow[t]{2}{*}{ One if French legal origin } & 0.097 & - & 0.001 & -0.251 & -0.047 & -0.347 \\
\hline & $(1.05)$ & - & $(0.01)$ & $(1.42)$ & $(0.30)$ & $(1.84)^{*}$ \\
\hline \multirow[t]{2}{*}{ One if German legal origin } & -0.309 & - & -0.206 & -0.138 & 0.080 & -0.521 \\
\hline & $(3.44) * *$ & - & $(1.63)$ & $(0.89)$ & $(0.67)$ & $(3.53)^{* *}$ \\
\hline \multirow[t]{2}{*}{ One if Scandinavian legal origin } & 0.302 & - & -0.096 & -0.472 & -0.127 & -0.215 \\
\hline & $(1.89)^{*}$ & - & $(0.84)$ & $(2.55)^{*}$ & $(0.71)$ & $(0.93)$ \\
\hline \multirow[t]{2}{*}{ One if Socialist legal origin } & -0.227 & - & -0.184 & -0.392 & -0.375 & 0.041 \\
\hline & $(3.98)^{* *}$ & - & $(1.41)$ & $(1.30)$ & $(1.33)$ & $(0.11)$ \\
\hline \multirow[t]{2}{*}{ Economic Development } & 0.093 & - & -0.056 & -0.207 & -0.222 & -0.112 \\
\hline & $(1.82)^{*}$ & - & $(1.18)$ & $(1.34)$ & $(1.37)$ & $(0.60)$ \\
\hline \multirow[t]{2}{*}{ Financial Development } & 0.164 & - & -0.115 & 0.045 & 0.028 & 0.138 \\
\hline & $(1.73)^{*}$ & - & $(1.33)$ & $(0.34)$ & $(0.15)$ & $(0.87)$ \\
\hline \multirow[t]{2}{*}{ Percentage change in GDP } & 0.001 & - & 0.002 & 0.005 & 0.005 & -0.003 \\
\hline & $(0.64)$ & - & $(1.10)$ & $(0.77)$ & $(1.11)$ & $(0.49)$ \\
\hline \multirow[t]{2}{*}{ Creditors' rights } & 0.063 & - & 0.098 & -0.012 & -0.020 & -0.019 \\
\hline & $(1.92)^{*}$ & - & $(2.84)^{* *}$ & $(0.24)$ & $(0.35)$ & $(0.48)$ \\
\hline \multirow[t]{2}{*}{ Legal formalism } & 0.066 & - & 0.135 & -0.025 & -0.045 & 0.283 \\
\hline & $(2.25)^{*}$ & - & $(4.35)^{* *}$ & $(0.24)$ & $(0.42)$ & $(2.23)^{*}$ \\
\hline \multirow[t]{2}{*}{ Property rights } & -0.210 & - & 0.027 & 0.151 & 0.017 & -0.051 \\
\hline & $(4.20)^{* *}$ & - & $(0.55)$ & $(1.65)^{*}$ & $(0.12)$ & $(0.49)$ \\
\hline \multirow[t]{2}{*}{ Corruption (higher means less corrupt) } & -0.028 & - & 0.091 & -0.006 & -0.058 & 0.024 \\
\hline & $(0.87)$ & - & $(2.97)^{* *}$ & $(0.09)$ & $(0.54)$ & $(0.22)$ \\
\hline Observations & 4,343 & & 8,883 & 695 & 3,046 & 562 \\
\hline Number of Countries & 46 & & 57 & 32 & 42 & 23 \\
\hline Rated? & No & & No & Yes & No & Yes \\
\hline R-squared (pseudo for probits) & 0.23 & & 0.32 & 0.47 & 0.46 & 0.75 \\
\hline Estimation Technique & Probit & & OLS & OLS & OLS & OLS \\
\hline
\end{tabular}

* Significant at $10 \% ; * *$ significant at $1 \%$ 
Table 9

Regressions Relating Loan Contract Terms to Country Characteristics (With Loan Ownership Variables Included as Regressors): Rated vs. Unrated Borrowers

Regressions contain year, ratings, 1-digit SIC industry, and loan purpose indicators. Loan observations are clustered by borrower country. We also include an indicator for loans denominated in a major currency, and an indicator for multinational companies. The source of data is LPC's Dealscan database. The sample of loans includes those originated in 1994 through the middle of 2003.

Loans to firms in financial or regulated industries, as well a public sector loans, are dropped (SIC 4, 6, and 9). Regressions without firm controls exclude ratings, industry, multinational indicators and log of loan commitment amount.

\begin{tabular}{|c|c|c|c|c|c|c|}
\hline \multirow[t]{2}{*}{ Explanatory Variable } & \multicolumn{2}{|c|}{ Secured Indicator } & \multicolumn{2}{|c|}{$\begin{array}{l}\text { Log of maturity in } \\
\text { Months }\end{array}$} & \multicolumn{2}{|c|}{$\begin{array}{l}\text { Log of Drawn All-in } \\
\text { Spread }\end{array}$} \\
\hline & (1) & (2) & (3) & (4) & (5) & $(6)$ \\
\hline \multirow[t]{2}{*}{ One if loan is a line of credit } & -0.044 & - & -0.554 & -0.356 & -0.284 & -0.378 \\
\hline & $(1.77)^{*}$ & - & $(4.00)^{* *}$ & $(2.32)^{*}$ & $(5.98)^{* *}$ & $(3.69)^{* *}$ \\
\hline \multirow[t]{2}{*}{ Log of loan commitment amount } & -0.045 & - & 0.010 & -0.071 & -0.163 & -0.144 \\
\hline & $(3.06)^{* *}$ & - & $(0.45)$ & $(1.90)^{*}$ & $(7.30)^{* *}$ & $(6.86)^{* *}$ \\
\hline \multirow[t]{2}{*}{ Log of Number of Lenders } & 0.067 & - & 0.018 & -0.049 & -0.015 & -0.017 \\
\hline & $(3.07)^{* *}$ & - & $(1.68)^{*}$ & $(1.10)$ & $(1.23)$ & $(0.55)$ \\
\hline \multirow[t]{2}{*}{ Share held by Government Banks } & 0.000 & - & 0.002 & -0.002 & -0.003 & -0.006 \\
\hline & $(0.63)$ & - & $(1.85)^{*}$ & $(0.35)$ & $(1.33)$ & $(1.56)$ \\
\hline \multirow[t]{2}{*}{ Share held by Domestic Banks } & 0.000 & - & 0.001 & -0.001 & -0.004 & -0.003 \\
\hline & $(0.10)$ & - & $(1.73)^{*}$ & $(0.80)$ & $(4.39)^{* *}$ & $(2.74)^{*}$ \\
\hline \multirow[t]{2}{*}{ One if French legal origin } & 0.084 & - & 0.003 & -0.235 & -0.038 & -0.349 \\
\hline & $(0.92)$ & - & $(0.03)$ & $(1.38)$ & $(0.27)$ & $(2.05)^{*}$ \\
\hline \multirow[t]{2}{*}{ One if German legal origin } & -0.316 & - & -0.224 & -0.096 & 0.150 & -0.453 \\
\hline & $(3.52)^{* *}$ & - & $(1.88)^{*}$ & $(0.62)$ & $(1.41)$ & $(3.10)^{* *}$ \\
\hline \multirow[t]{2}{*}{ One if Scandinavian legal origin } & 0.328 & - & -0.111 & -0.476 & -0.160 & -0.270 \\
\hline & $(2.05)^{*}$ & - & $(0.98)$ & $(2.54)^{*}$ & $(0.93)$ & $(1.21)$ \\
\hline \multirow[t]{2}{*}{ One if Socialist legal origin } & -0.236 & - & -0.191 & -0.409 & -0.415 & -0.031 \\
\hline & $(3.82)^{* *}$ & - & $(1.47)$ & $(1.38)$ & $(1.64)$ & $(0.09)$ \\
\hline \multirow[t]{2}{*}{ Economic Development } & 0.100 & - & -0.049 & -0.203 & -0.167 & -0.116 \\
\hline & $(1.98) *$ & - & $(1.05)$ & $(1.41)$ & $(1.22)$ & $(0.66)$ \\
\hline \multirow[t]{2}{*}{ Financial Development } & 0.175 & - & -0.123 & 0.015 & -0.025 & 0.048 \\
\hline & $(1.77)^{*}$ & - & $(1.50)$ & $(0.13)$ & $(0.14)$ & $(0.30)$ \\
\hline \multirow[t]{2}{*}{ Percentage change in GDP } & 0.001 & - & 0.002 & 0.005 & 0.004 & -0.003 \\
\hline & $(0.53)$ & - & (1.15) & $(0.87)$ & $(1.11)$ & $(0.54)$ \\
\hline \multirow[t]{2}{*}{ Creditors' rights } & 0.072 & - & 0.102 & -0.007 & -0.014 & -0.006 \\
\hline & $(2.26)^{*}$ & - & $(2.98)^{* *}$ & $(0.14)$ & $(0.27)$ & $(0.16)$ \\
\hline \multirow[t]{2}{*}{ Legal formalism } & 0.065 & - & 0.128 & -0.029 & -0.040 & 0.289 \\
\hline & $(2.20)^{*}$ & - & $(4.14)^{* *}$ & $(0.29)$ & $(0.41)$ & $(2.46)^{*}$ \\
\hline \multirow[t]{2}{*}{ Property rights } & -0.224 & - & 0.023 & 0.146 & -0.013 & -0.091 \\
\hline & $(4.55)^{* *}$ & - & $(0.49)$ & $(1.58)$ & $(0.10)$ & $(1.03)$ \\
\hline \multirow[t]{2}{*}{ Corruption (higher means less corrupt) } & -0.029 & - & 0.090 & 0.001 & -0.047 & 0.064 \\
\hline & $(0.90)$ & - & $(3.05)^{* *}$ & $(0.06)$ & $(0.51)$ & $(0.66)$ \\
\hline Observations & 4,343 & & 8,883 & 695 & 3,046 & 562 \\
\hline Number of Countries & 46 & & 57 & 32 & 42 & 23 \\
\hline Rated? & No & & No & Yes & No & Yes \\
\hline R-squared (pseudo for probits) & 0.24 & & 0.33 & 0.47 & 0.47 & 0.75 \\
\hline Estimation Technique & Probit & & OLS & OLS & OLS & OLS \\
\hline
\end{tabular}

* Significant at $10 \%$;* significant at $1 \%$ 